\title{
Modelling the Symmetrical and Asymmetrical Effects of Global Oil Prices on Local Food Prices: A MENA Region Application
}

Hadj Cherif Houda

Beijing Technology and Business University

Zhenling Chen ( $\nabla$ chenzhenling2008@163.com )

Beijing Technology and Business University

Guohua Ni

Beijing Technology and Business University

\section{Research Article}

Keywords: Oil prices, Food prices, MENA region, Panel ARDL, Symmetry and Asymmetry.

Posted Date: April 19th, 2021

DOl: https://doi.org/10.21203/rs.3.rs-394222/v1

License: (c) (i) This work is licensed under a Creative Commons Attribution 4.0 International License.

Read Full License

Version of Record: A version of this preprint was published at Environmental Science and Pollution Research on July 28th, 2021. See the published version at https://doi.org/10.1007/s11356-021-14842-1. 


\section{Modelling the symmetrical and asymmetrical effects of global oil 2 prices on local food prices: A MENA region application}

3 Hadj Cherif Houda ${ }^{1}$, Zhenling Chen ${ }^{1,2^{*}}$, Guohua $\mathrm{Ni}^{1 * *}$

4 Abstract: This paper explores the complex nexus between the global oil prices and the food prices of Middle East and North Africa (MENA) region during the period 2000-2020. Both linear and nonlinear models of the autoregressive distributed lag (ARDL) approach are adapted into panel data form to investigate the symmetrical and asymmetrical influence of oil prices on food prices. The key results are summarized: i) The effect of oil prices on food prices is significantly positive including both oil-exporting and oil-importing nations are verified in the long-term. The positive impact on oil-exporters - due to higher oil revenues - is greater than importing nations, leading to an increased demand for food. Additionally, the effect on oilexporters is negative and significant in the short-term but not significant for importers. ii) The panel analysis for the MENA sample confirms the presence of negative short-term asymmetric behaviour, while in the long-term, the asymmetric effect is positive, indicating that food prices increase regardless of fluctuations in oil prices. iii) Wald test results support asymmetric cointegration for the whole sample of the MENA due to the heterogeneous response within the oil-importing and exporting samples. Specifically, the non-linear ARDL test results affirm the absence of an asymmetric nexus among oil and food prices for oil-exporting group (including Saudi Arabia, Saudi Arabia, United Arab Emirates) and Tunisia within the oil-importing group. Although there are differences in the direction and degree, the food prices of other countries

1. School of Economics, Beijing Technology and Business University, No.33 Fucheng Road, Haidian District, Beijing, 100048, China.

2. Collaborative Innovation Center of Urban-Rural Coordinated Development, Henan University of Economics and Law, No.180 Jinshui East Road, Zhengzhou,450046, China

*Corresponding author at: School of Economics, Beijing Technology and Business University,Beijing 100048, China.

**Corresponding author at: School of Economics, Beijing Technology and Business University,Beijing 100048, China.

Email addresses: chenzhenling2008@163.com (Z.Chen); 
are asymmetric to the oil price. This study provides recommendations that are useful to MENA countries to establish a stable mechanism for oil and food prices to ensure food security in the region.

Keywords: Oil prices; Food prices; MENA region; Panel ARDL; Symmetry and Asymmetry.

\section{Introduction}

As important strategic resources, food and oil have been widely studied by scholars (Dalheimer et al., 2021; Mokni and Ben-Salha, 2020; Sarwar et al., 2020). In recent years, international food prices have continued to rise. Many reasons contribute to rising prices of food; however, high oil prices are a major factor. The expansion of biomass energy—such as biodiesel and bioethanol - in response to climate change has caused a crowding-out effect on food production for people, while high oil prices have increased agricultural costs incurred in the production and transportation processes (Gardebroek and Hernandez, 2013; Sarwar et al., 2020; Dalheimer et al., 2021). Rising food prices have posed a substantial threat to food security especially for countries that rely heavily on importing food. The UN Secretary-General Ban Ki-Moon noted that global food prices rose by more than 50\% in 2007 alone. This severe situation, and the double crisis caused by rising energy prices, threatened the international community's plan to achieve their Millennium Development Goals in 2015. It is estimated that if food prices increase 50-80\%, many people will face malnutrition and hunger. Consequently, recognizing the internal relationship among food oil and oil prices is an important prerequisite to stabilizing food prices and establishing an early warning mechanism. However, due to the huge differences in terms of resource endowment, agricultural productivity, and economic status among regions of the world, the relationship between the two prices can have distinguish mechanism. For example, countries rich in agricultural products will be much less affected by high oil prices than countries with poor supply capacity of agricultural products. Therefore, the internal relationship between food and oil prices should be analysed according to the research objective. 
As for the region of Middle East and North Africa (MENA), researching how oil prices affects food prices is even more important. The main reasons are: 1) Most countries are net importers of food commodities as food crops are difficult to cultivate due to insufficient water supply and limited access to arable land. They are particularly vulnerable to fluctuations in international commodity markets and are most seriously affected by rising prices. Therefore, stable food prices and reliable sourcing of imports are the basis for food security in these countries; 2) Some countries that are rich in oil resources but lacking in food have implemented the strategy of the 'Oil for Food programme'. The rising oil price will attract great economic benefits, but more will have to be spent on buying food. Thus, the social welfare of these countries is uncertain given the volatility of oil and food prices; 3) Although MENA countries are geographically concentrated, the resources and economic conditions of these countries are vastly different. Only certain countries are rich in oil products. Therefore, for oil-importing countries (oilimporters) and oil-exporting countries (oil-exporters), international oil prices can exhibit differing impact mechanisms on local food prices. Researching the influence of oil prices on the MENA region's food prices — where food is primarily dependent on imports — is of great significance in establishing a stable food price mechanism and to ensure regional security.

Consequently, this study will focus on exploring the distinctive mechanisms impacting oil and food prices in the MENA region by comparing oil-exporters to oil-importers. This research is among the first to focus on examining this from a MENA perspective. Previous studies often using time series which cannot capture inter-group information and eliminate the individual fixed effect; this study explores such relationship using a panel data sample. Considering food prices may appear similar or dissimilar as oil prices fluctuate, the research builds linear and non-linear Autoregressive distributed lag (ARDL) modelling method to address symmetrical and asymmetrical inter linkage between the price food and oil. The contributions of this study are: i) focusing on a specific group of countries in the MENA region to determine the impacts of 
the oil price on their food prices; ii) Focusing on a comparative exploration on the subject by comparing oil exporters with oil importers. iii) Simultaneously, the symmetrical and asymmetrical interactions in the food-oil price nexus are captured by applying panel data from oil-exporters and importers of the MENA region. The remainder of this paper has the following structures: in section 2 the research literature relating to food-oil prices nexus is summarized; Section 3 highlights the panel symmetric and asymmetric ARDL models; in section 4 the data and indicators used for the study are presented; Section 5 discusses the empirical application for MENA countries from 2000 to 2020; and the paper concludes with Section 6, which discusses policy implications.

\section{Literature review}

Substantial research on food and oil markets was stimulated by the 2008 global food crisis. The volatility of the crude oil price affects food commodities through increasing fertilizer costs, transportation costs, and fuels for agricultural machinery and so on (Chen et al. (2019). The existing studies contends that food prices are significantly and positively related to the oil price. For instance, Chen et al. (2010) using the ARDL model, detected that crude oil fluctuations and other grain market fluctuations have a significant impact on the price of grain. Esmaeili and Shokoohi (2011) using a principal component analysis to investigate the nexus between the global oil price, world prices of food and other macroeconomic variables. Their findings revealed that the price of oil influences food prices in an indirect way, as confirmed by Pal and Mitra (2018), Gohin and Chantret (2010), and Ciaian and Kancs (2011). However, some scholars have found that the food prices is not influenced by oil price fluctuations. For example, Reboredo (2012) examined co-movements among the global oil price and those of wheat, corn, soybeans by applying copulas. His results indicated that the increase in food price was not caused by volatility in oil prices. Therefore it supports neutrality against oil price fluctuations in agricultural markets. Baumeister and Kilian (2014) confirmed that shocks in oil prices are 
not linked to food prices in the United States due to the small contribution of agricultural commodities to total food prices. Another analysis containing the volatility transmission of corn, oil and ethanol prices was performed by Gardebroek and Hernandez (2013). They found there is no major fluctuations in the energy market that boost price variability on the corn market.

Due to the differences in the selected samples and the complexity of the relationships between them, it is difficult to reach a consensus from the literature. Increasingly, scholars believe this is a complex nonlinearity relationship. Using Malaysia as a case, Ibrahim (2015) reported the presence of short- and long-run asymmetries in food prices behaviour when oil price increases led to increasing food prices - but there was no association between the decline in oil prices and food prices. The potential asymmetry for transit from the price of oil to food is also analysed in an Indian context (Pal and Mitra, 2016).For an oil-dependent emerging economy as Nigeria, Nwoko et al. (2016) investigated the causal link between food and oil prices volatility and concluded that the causality from oil prices to aggregate food price fluctuations is unidirectional. Olayungbo and Hassan (2016) examined the symmetric interactions between food and oil prices between oil and food prices of oil-exporters by applying a panel ARDL approach. The long-run finding indicated that oil prices affected food prices positively and significantly while the short-term impact was similarly positive and significant. These results were verified by Meyer et al. (2018).

As the hub connecting Asia, Europe, and Africa and the most important oil-producing region in the world, the MENA region has garnered much attention. Ek Fälth et al. (2020) explored the impact of nuclear energy, land availability, and the expansion of transmission on the cost of electricity from renewable sources by comparing MENA region to Europe. Kassouri and Altıntaş (2020) examined the trade-off regarding environmental and human well-being issues. Bellakhal et al. (2019) focused on the interaction impact between governance and trade 
openness on investments in renewable energy in the MENA region over the period 1996-2013. Apergis et al. (2014) investigated the Dutch disease impact of oil rents on added value for the agricultural sector in oil-producers of MENA region, establishing a long-run negative relationship that relatively slowly re-equilibrium with an added agricultural value following a boom in oil rents. Although previous literature has investigated many aspects of the MENA region, the mechanism influencing food and oil prices has been neglected.

In conclusion, although there are considerable researches on the effects of oil price on food price, there are few studies that examine and explore how oil price influences food prices using a sample of MENA nations. Previous studies on this issue have always used time series which cannot capture group information or mitigate individual fixed effects. Consequently, this study explores this relationship using panel linear and non-linear ARDL models to assess both shortterm and long-term dynamic interactions between food and oil prices for MENA countries.

\section{Indicators and data}

To explore the association of food and oil prices in MENA countries, this study employs panel data of food prices $(F D P)$ from 2000 to 2020 for 14 countries of the MENA region and annual time series data of the global oil price $(O L P)$. Referring to previous literature (e.g. Meyer et al., 2018; Olayungbo and Hassan, 2016; Taghizadeh-hesary et al., 2019), additional panel data such as the inflation rate $(I N F)$, the degree of trade openness $(T O)$, and urbanization levels (URB) are chosen as control variables. Given data availability, we only obtain time series annual data for the global oil price (the average of two major types of crude oil: Brent and WTI). Food prices in the MENA region are transformed by consumer prices indices to actual values for the base period $(2015=100)$. The degree of trade openness $(T O)$ is expressed as a percentage of total imports and exports to Gross Domestic Product (GDP); and the urbanization level (URB) is measured as the urban population ratio. The relevant data was derived from the Energy Information Administration (EIA), the (BP) Statistical Review of World Energy, the Food and 

shown in Table 1.

148 Table 1 Specific indicators for variables

\begin{tabular}{lllll}
\hline Dimension & Indicator & Symbol & Log form symbol & Data source \\
\hline Local Food prices & $\begin{array}{l}\text { Food consumer } \\
\text { prices }\end{array}$ & FDP & LFDP & FAO \\
\hline Global oil price & $\begin{array}{l}\text { The Brent and WTI } \\
\text { average }\end{array}$ & OLP & LOLP & BP,EIA \\
\hline $\begin{array}{l}\text { The degree of trade } \\
\text { openness }\end{array}$ & $\begin{array}{l}\text { The percentage of } \\
\text { total imports and } \\
\text { exports to GDP }\end{array}$ & LTO & The World Bank Database \\
\hline Inflation rate & $\begin{array}{l}\text { The percentage } \\
\text { rate of change in } \\
\text { prices level } \\
\text { The ratio of urban } \\
\text { population to the } \\
\text { total population }\end{array}$ & LINF & LURB & The World Bank Database \\
\hline Urbanization level & & & The World Bank Database \\
\hline
\end{tabular}

The sample countries were divided into two groups to analyse the data more precisely:

150 Group 1: Oil-exporters group (Algeria, Bahrain, Iraq, Kuwait, Oman, Qatar, Saudi Arabia and

151 UAE). Group 2: Oil-importers group (Jordan, Lebanon, Tunisia, Morocco, Egypt, West Bank and

152 Gaza).

153 Table 2 provides descriptive statistics. For the oil-exporters sample, the mean of food prices $154(F D P)$ is greater than for oil-importers (81.702). The oil price $(O L P)$ has a volatility of 25.704 155 based on its standard deviation, which denotes some shocks between 2000 and 2020. Inflation 156 rate $(I N F)$ among the oil-exporting group has a maximum value of $53.231 \%$ and minimum of $15710.067 \%$, whereas those values for oil-importers reach $29.602 \%$ and $-3.749 \%$, respectively. The 158 degree of trade openness $(T O)$ among the MENA region has a mean of $92.768 \%$, with a 159 maximum of $191.872 \%$, and a minimum of $30.247 \%$. Finally, the mean of the urbanization level $160(U R B)$ for oil-exporters (83.294\%) is higher than for oil-importers (69.049\%). Overall, different 161 connected mechanisms for food and oil prices in the two types of nations are clearly indicated.

162 Table 2 Statistics of descriptive variables

\begin{tabular}{llllll}
\hline Variable & Obs. & Min. & Max. & Mean & Std.Dev. \\
\hline Oil- exporting countries & & & & & \\
\hline FDP & 168 & 33.342 & 122.646 & 83.885 & 19.138 \\
OLP & 168 & 25.325 & 103.27 & 63.161 & 25.704 \\
$I N F$ & 168 & -10.067 & 53.231 & 3.616 & 6.596
\end{tabular}




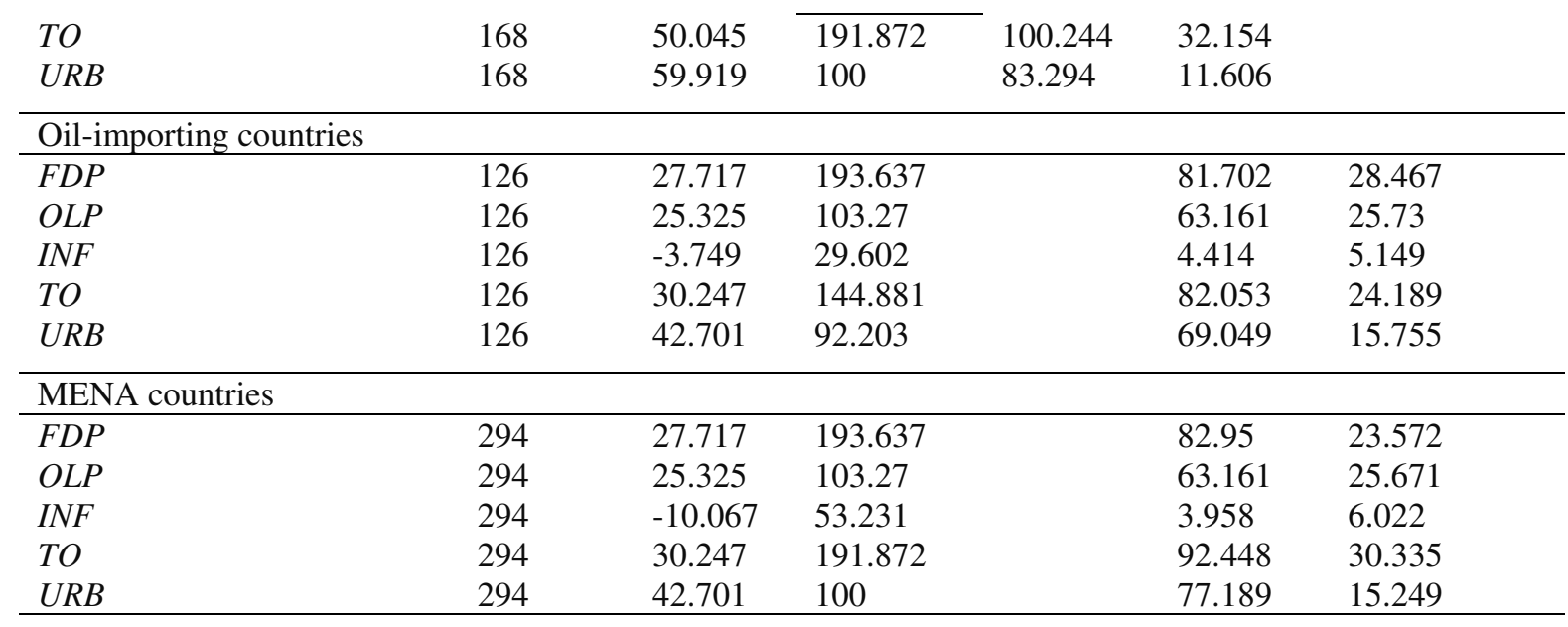

163 Table 3 shows the correlation matrix among variables. For the MENA countries there is a 164 positive correlation between food prices (FDP) and oil prices (OLP). The inflation rate (INF)

165 is positively correlated with food prices (FDP), except for oil-exporters where there is a 166 negative correlation. Furthermore, the degree of trade openness (TO) negatively correlated with 167 food prices (FDP) for oil-importers and the MENA region, and the relation between 168 urbanization level (URB) and food prices (FDP) is positive for oil-exporters. These results 169 indicate there is no potential multi-collinearity problem.

$170 \quad$ Table 3 Matrix of correlations among variables

\begin{tabular}{|c|c|c|c|c|c|}
\hline Variable & $F D P$ & $O L P$ & $I N F$ & TO & $U R B$ \\
\hline \multicolumn{6}{|c|}{ Oil- exporting countries } \\
\hline$F D P$ & 1.000 & & & & \\
\hline$O L P$ & 0.427 & 1.000 & & & \\
\hline INF & -0.270 & 0.063 & 1.000 & & \\
\hline TO & 0.001 & 0.167 & 0.053 & 1.000 & \\
\hline$U R B$ & 0.183 & 0.062 & -0.200 & 0.298 & 1.000 \\
\hline \multicolumn{6}{|c|}{ Oil-importing countries } \\
\hline$F D P$ & 1.000 & & & & \\
\hline$O L P$ & 0.286 & 1.000 & & & \\
\hline$I N F$ & 0.331 & 0.172 & 1.000 & & \\
\hline TO & -0.046 & 0.224 & -0.297 & 1.000 & \\
\hline$U R B$ & 0.128 & 0.061 & -0.458 & 0.599 & 1.000 \\
\hline \multicolumn{6}{|c|}{ MENA countries } \\
\hline$F D P$ & 1.000 & & & & \\
\hline$O L P$ & 0.346 & 1.000 & & & \\
\hline$I N F$ & 0.006 & 0.102 & 1.000 & & \\
\hline TO & -0.005 & 0.177 & -0.071 & 1.000 & \\
\hline$U R B$ & 0.154 & 0.054 & -0.298 & 0.486 & 1.000 \\
\hline
\end{tabular}


172 This article specified the recent method proposed by Pesaran et al. (2001) of the autoregressive 173 distributed lag (ARDL) boundary testing to determine the influence of global oil prices on 174 MENA countries' local food prices. This approach has many advantages compared to classical co-integration models (e.g. Engle and Granger, 1987; Johansen and Juselius, 1990), including: i) Estimations of both short- and long-term coefficients can be captured simultaneously; ii) it is practicable even if $\mathrm{I}(0)$ or $\mathrm{I}(1)$ or combination of any of the regressors are used ; iii) prevent endogeneity issues by taking into consideration a small sample and producing better outcomes over other co-integration methods. All variables are logarithmically transformed to address the potential heteroskedasticity problem. We construct panel linear ARDL and non-linear ARDL models according to Shin et al. (2014) and Salisu and Isah (2017) to detect the existence of symmetrical and asymmetrical relationships among global oil prices and local food prices.

\section{The panel linear ARDL Model}

Given the assumption that oil prices have a symmetric influence on food prices - the effect is similar if oil prices increase or decrease — and referring to Salisu and Isah (2017), the following formula is expressed by a symmetric form of linear ARDL:

$$
\Delta\left(L F D P_{t}\right)=\sum_{i=1}^{q} \beta_{1 i} \cdot \Delta\left(L F D P_{t-i}\right)+\sum_{i=0}^{p} \beta_{2 i} \cdot \Delta\left(L O L P_{t-i}\right)+\sum_{i=0}^{p} \beta_{3 i} \cdot \Delta\left(L I N F_{t-i}\right)+
$$

$\sum_{i=0}^{p} \beta_{4 i} \cdot \Delta\left(L T O_{t-i}\right)+\sum_{i=0}^{p} \beta_{5 i} \cdot \Delta\left(L U R B_{t-i}\right)+\alpha_{1} L F D P_{t-1}+\alpha_{2} L O L P_{t-1}+\alpha_{3} L I N F_{t-1}+$

$\alpha_{4} L T O_{t-1}+\alpha_{5} L U R B_{t-1}+\mu_{i}+\varepsilon_{i t}$

Where:

$\Delta$ is defined as the operator of differences; $i=1,2, \ldots, N$ refers to each country's numbers; $t$ $=1,2, \ldots, T$ denotes the time periods; $p$ and $q$ represent the optimum lag for dependent and independent variables, respectively; and $u_{i}$ is the group-specific effect. The residuals $\varepsilon_{i t}$ are assumed to be white noise. $\beta_{1 i}, \beta_{2 i}, \beta_{3 i}, \beta_{4 i}, \beta_{5 i}$ are the parameters for short-term while $\alpha_{1}, \alpha_{2}, \alpha_{3}, \alpha_{4}, \alpha_{5}$ are the parameters for long-term. 
To estimate short-term dynamic coefficients (e.g. Kun et al., 2015), the equation (1) has been re-specificated by using the model of panel error correction model (ECM) as:

$$
\begin{gathered}
\Delta\left(L F D P_{t}\right)=\sum_{i=1}^{q} \beta_{1 i} \cdot \Delta\left(L F D P_{t-i}\right)+\sum_{i=0}^{p} \beta_{2 i} \cdot \Delta\left(L O L P_{t-i}\right)+\sum_{i=0}^{p} \beta_{3 i} \cdot \Delta\left(L I N F_{t-i}\right)+ \\
\sum_{i=0}^{p} \beta_{4 i} \cdot \Delta\left(L T O_{t-i}\right)+\sum_{i=0}^{p} \beta_{5 i} \cdot \Delta\left(L U R B_{t-i}\right)+\lambda_{i} E C T_{t-1}+\mu_{i}+\varepsilon_{i t}
\end{gathered}
$$

Where:

The co-integration term: $\mathrm{ECT}_{t-1}=L F D P_{t-1}-\alpha_{1 i} L O L P_{t-1}-\alpha_{2 i} L I N F_{t-1}-\alpha_{3 i} L T O_{t-1}-$ $\alpha_{4 i} L U R B_{t-1}$ is referred to the error correction term (ECT). ? ? ${ }_{i}$ is the coefficient of speed adjustment in error correction model towards a long-term equilibrium and is required to be significant and negative. $\beta_{1 i}, \beta_{2 i}, \beta_{3 i}, \beta_{4 i}, \beta_{5 i}$ are short-run coefficients as shown in equation (1).

\section{The panel non-linear ARDL Model}

In contrast to the symmetric linear ARDL Model, asymmetries are calculated in this case to investigate food price asymmetric reactions to oil prices by decomposing the sum of negative and positive partial following Salisu and Isah (2017) and Shin et al. (2014). According to this model, positive and negative oil price shocks are not assumed to affect the price of food similarly. The ARDL model can therefore be expressed nonlinear in the following form:

$\Delta\left(L F D P_{t}\right)=\sum_{i=1}^{q} \beta_{1 i} \cdot \Delta\left(L F D P_{t-i}\right)+\sum_{i=0}^{p} \beta_{2 i}^{+} \cdot \Delta\left(L O L P_{t-i}^{+}\right)+\sum_{i=0}^{p} \beta_{3 i}^{-} \cdot \Delta\left(L O L P_{t-i}^{-}\right)+$ $\sum_{i=0}^{p} \beta_{4 i} \cdot \Delta\left(L I N F_{t-i}\right)+\sum_{i=0}^{p} \beta_{5 i} \cdot \Delta\left(L T O_{t-i}\right)+\sum_{i=0}^{p} \beta_{6 i} \cdot \Delta\left(L U R B_{t-i}\right)+\alpha_{1} L F D P_{t-1}+$

$\alpha_{2} L O L P_{t-1}^{+}+\alpha_{3} L O L P_{t-1}^{-}+\alpha_{4} L I N F_{t-1}+\alpha_{5} L T O_{t-1}+\alpha_{6} L U R B_{t-1}+\mu_{i}+\varepsilon_{i t}$

Where:

$L O L P^{-}$and $L O L P^{+}$represent the logarithm of partial sums for changes in negative and positive oil prices, indicating respectively negative and positive oil price shocks:

$$
\begin{aligned}
& L O L P_{t}^{+}=\sum_{j=1}^{t} \Delta L O L P_{i j}^{+}=\sum_{j=1}^{t} \max \left(\Delta L O L P_{i j}, 0\right) \\
& L O L P_{t}^{-}=\sum_{j=1}^{t} \Delta L O L P_{i j}^{-}=\sum_{j=1}^{t} \min \left(\Delta L O L P_{i j}, 0\right)
\end{aligned}
$$




$$
L O L P_{t}^{+}=\sum_{j=1}^{t} \Delta L O L P_{i j}^{+}=\sum_{j=1}^{t} \max \left(\Delta L O L P_{i j}, 0\right)
$$

$$
L O L P_{t}^{-}=\sum_{j=1}^{t} \Delta L O L P_{i j}^{-}=\sum_{j=1}^{t} \min \left(\Delta L O L P_{i j}, 0\right)
$$

222 Since we added the error correction term of the linear model in Equation (1), we likewise utilize this term for the non-linear version as follows :

$$
\begin{aligned}
& \Delta\left(L F D P_{t}\right)=\sum_{i=1}^{q} \beta_{1 i} \cdot \Delta\left(L F D P_{t-i}\right)+\sum_{i=0}^{p} \beta_{2 i}^{+} \cdot \Delta\left(L O L P_{t-i}^{+}\right)+\sum_{i=0}^{p} \beta_{3 i}^{-} \\
& \Delta\left(L O L P_{t-i}^{-}\right)+\sum_{i=0}^{p} \beta_{4 i} \cdot \Delta\left(L I N F_{t-i}\right)+\sum_{i=0}^{p} \beta_{5 i} \cdot \Delta\left(L T O_{t-i}\right)+\sum_{i=0}^{p} \beta_{6 i} \cdot \Delta\left(L U R B_{t-i}\right)+ \\
& \lambda_{i} E C T_{t-1}+\mu_{i}+\varepsilon_{i t}
\end{aligned}
$$

The error-correction term $E C T_{t-1}$ captures the long-term equilibrium of the nonlinear panel ARDL is captured by the error-correction term $E C T_{t-1}$ as equation (2). $\lambda_{i}$ is an error-correction parameter that determines the speed at which the independent variable adjusts to reach its longterm equilibrium as a result of shocks in the dependent variable.

\section{Results and discussions}

\section{Data Stationary Test Result}

As a prerequisite for selecting an econometric model, panel unit root tests are applied on each variable to ensure that the data used are stationary at levels or first-order differences. With the chosen samples being countries, we suspend the cross-section dependence across them in our model. We utilized the cross-sectional dependence Pesaran CD test to assure this assumption. The CD-test findings indicate the presence of cross-sections in all variables, as shown in Table 4, where the statistical values were significant at $1 \%$, indicating that the sample countries share the same characteristics.

Table 4 Cross-sectional dependence test

\begin{tabular}{llll}
\hline \multirow{2}{*}{ Variables } & Oil-exporting countries & Oil-importing countries & MENA countries \\
\cline { 2 - 4 } & CD-test & CD-test & CD-test \\
\hline lFDP & $16.178^{* * *}$ & $16.842^{* * *}$ & $34.553^{* * *}$ \\
& $(0.000)$ & $(0.000)$ & $(0.000)$ \\
\hline LOLP & $24.249^{* * *}$ & $17.748^{* * *}$ & $43.715^{* * *}$ \\
& $(0.000)$ & $(0.000)$ & $(0.000)$ \\
\hline
\end{tabular}




\begin{tabular}{llll}
\hline LINF & $6.418 * * *$ & $2.239 * *$ & $8.512 * * *$ \\
& $(0.000)$ & $(0.025)$ & $(0.000)$ \\
\hline \multirow{2}{*}{ LTO } & $3.984 * * *$ & $5.29 * * *$ & $8.683 * * *$ \\
& $(0.000)$ & $(0.000)$ & $(0.000)$ \\
\hline LURB & $19.707 * * *$ & $9.505 * * *$ & $30.881 * * *$ \\
& $(0.000)$ & $(0.000)$ & $(0.000)$ \\
\hline
\end{tabular}

Table 5 CADF test results

\begin{tabular}{lllllll}
\hline \multirow{2}{*}{ Variables } & \multicolumn{2}{c}{ Oil-exporting countries } & \multicolumn{2}{c}{ Oil-importing countries } & \multicolumn{2}{c}{ MENA countries } \\
\cline { 2 - 7 } & \multicolumn{2}{c}{ Zt-bar } & \multicolumn{2}{c}{ Zt-bar } & \multicolumn{2}{c}{ Zt-bar } \\
\cline { 2 - 7 } & Level & F.difference & Level & F.difference & level & F.difference \\
\hline \multirow{2}{*}{ LFDP } & $-1.675^{* *}$ & $-2.722^{*} *$ & 0.861 & $-3.464 * * *$ & -0.820 & $-3.049 * * *$ \\
& $(0.047)$ & $(0.003)$ & $(0.805)$ & $(0.000)$ & $(0.206)$ & $(0.001)$ \\
\hline LOLP & 12.743 & 11.918 & 11.035 & 10.321 & 16.895 & 15.994 \\
& $(1.000)$ & $(1.000)$ & $(1.000)$ & $(1.000)$ & $(1.000)$ & $(1.000)$ \\
\hline LINF & -0.945 & $-4.753^{* * *}$ & 0.344 & $-6.428 * * *$ & -1.159 & $-6.574 * * *$ \\
& $(0.172)$ & $(0.000)$ & $(0.634)$ & $(0.000)$ & $(0.123)$ & $(0.000)$ \\
\hline LTO & 0.325 & $-3.029^{* * *}$ & 1.225 & $-1.891 * *$ & 1.547 & $-3.176^{* * *}$ \\
& $(0.627)$ & $(0.001)$ & $(0.890)$ & $(0.029)$ & $(0.939)$ & $(0.001)$ \\
\hline LURB & 1.101 & $-3.346^{* *}$ & $-2.317 * *$ & 3.049 & $-1.723 * *$ & 6.478 \\
& $(0.864)$ & $(0.002)$ & $(0.010)$ & $(0.999)$ & $(0.042)$ & $(1.000)$
\end{tabular}

Note. The Pesaran's CADF-test is based upon the null hypothesis that series are integrated at I (1).

Note. (1)The CD test is based upon the null hypothesis of the cross-section independence tends to $\mathrm{N}(0,1)$. A p-value near zero indicates the correlation between panel sets.

(2) Parentheses denote probability values, while ***,*** represent a 1\%, 5 and 10\%, respectively, of significance.If no special instructions, the following symbols are the same.

Given the cross-section dependencies among countries, first-generation panel unit root tests such as Levin Lin and Chu (LLC), Im Pesaran and Shin (IPS) tests are unsuitable. Hence, we employ the Cross-sectional Augmented Dickey-Fuller (CADF) Pesaran test (Pesaran, 2007) for checking the stationarity levels of the variables in the sample countries. The findings of the CADF tests indicate in Table 5 that the variables considered in our study are not integrated at an order greater than I (1). These levels of integration confirm the convenience of the panel ARDL approach.

\section{4}

\section{Food prices symmetrical response to oil prices}

The estimated symmetric impact is summarized in Table 6 using equation (1). Here, all the equations are estimated with pooled mean group (PMG) of dynamic heterogeneous panels (Pesaran et al., 1999), Pesaran and Smith's (1995) mean group estimator (MG), and the

\footnotetext{
${ }^{2}$ Here the oil price variable is non-stationary because oil price only have the time change and no changes across countries.
} 
259 are not significant which indicates that the PMG is the adequate estimator in all sample

260 countries for modelling the symmetric nexus among food prices and oil prices. Thus, we accept

261 the estimated results for PMG methods.

262 Table 6 Symmetric ARDL model results

\begin{tabular}{|c|c|c|c|c|c|c|c|c|c|}
\hline \multirow[b]{2}{*}{ Variables } & \multicolumn{3}{|c|}{ Oil-exporting countries } & \multicolumn{3}{|c|}{ Oil-importing countries } & \multicolumn{3}{|c|}{ MENA countries } \\
\hline & PMG & $\mathrm{MG}$ & DFE & PMG & MG & DFE & PMG & MG & DFE \\
\hline \multicolumn{10}{|l|}{ Long-run } \\
\hline$L O L P_{t-1}$ & $\begin{array}{l}0.334 * * * \\
(0.000)\end{array}$ & $\begin{array}{l}-0.0758 \\
(0.650)\end{array}$ & $\begin{array}{l}0.341 * * * \\
(0.000)\end{array}$ & $\begin{array}{c}0.269 * * * \\
(0.000)\end{array}$ & $\begin{array}{l}0.166^{*} \\
(0.024)\end{array}$ & $\begin{array}{l}-6.390 \\
(0.721)\end{array}$ & $\begin{array}{c}0.274 * * * \\
(0.000)\end{array}$ & $\begin{array}{l}0.027 \\
(0.787)\end{array}$ & $\begin{array}{l}1.652 \\
(0.666)\end{array}$ \\
\hline$L I N F_{t-1}$ & $\begin{array}{l}0.0499 * * \\
(0.012)\end{array}$ & $\begin{array}{l}0.245 \\
(0.092)\end{array}$ & $\begin{array}{l}0.0414 \\
(0.687)\end{array}$ & $\begin{array}{l}0.0375 * \\
(0.062)\end{array}$ & $\begin{array}{l}0.268^{*} \\
(0.072)\end{array}$ & $\begin{array}{l}-6.011 \\
(0.709)\end{array}$ & $\begin{array}{l}0.0464 * * \\
(0.002)\end{array}$ & $\begin{array}{l}0.255 * * \\
(0.011)\end{array}$ & $\begin{array}{l}1.729 \\
(0.679)\end{array}$ \\
\hline$L T O_{t-1}$ & $\begin{array}{l}-0.357 * * \\
(0.016)\end{array}$ & $\begin{array}{l}0.295 \\
(0.616)\end{array}$ & $\begin{array}{l}0.175 \\
(0.473)\end{array}$ & $\begin{array}{l}-0.416^{* * *} \\
(0.000)\end{array}$ & $\begin{array}{l}-0.293 \\
(0.177)\end{array}$ & $\begin{array}{l}4.807 \\
(0.805)\end{array}$ & $\begin{array}{l}-0.369 * * * \\
(0.000)\end{array}$ & $\begin{array}{l}0.0430 \\
(0.901)\end{array}$ & $\begin{array}{l}-0.352 \\
(0.908)\end{array}$ \\
\hline$L U R B_{t-1}$ & $\begin{array}{l}2.385^{* * * *} \\
(0.000)\end{array}$ & $\begin{array}{l}145.9 \\
(0.211)\end{array}$ & $\begin{array}{l}1.163 \\
(0.478)\end{array}$ & $\begin{array}{l}2.035^{* * * *} \\
(0.000)\end{array}$ & $\begin{array}{l}-4.971 \\
(0.741)\end{array}$ & $\begin{array}{l}40.37 \\
(0.684)\end{array}$ & $\begin{array}{l}2.081 * * * \\
(0.000)\end{array}$ & $\begin{array}{l}81.22 \\
(0.234)\end{array}$ & $\begin{array}{l}-10.36 \\
(0.738)\end{array}$ \\
\hline$E C T$ & $\begin{array}{l}-0.314^{*} \\
(0.062) \\
\end{array}$ & $\begin{array}{l}-0.529 * * \\
(0.013)\end{array}$ & $\begin{array}{l}-0.107 * * * \\
(0.000)\end{array}$ & $\begin{array}{l}-0.442 * * * \\
(0.000)\end{array}$ & $\begin{array}{l}0.167 \\
(0.177)\end{array}$ & $\begin{array}{l}0.00493 \\
(0.666)\end{array}$ & $\begin{array}{l}-0.244 * * \\
(0.015)\end{array}$ & $\begin{array}{l}-0.492 * * * \\
(0.000)\end{array}$ & $\begin{array}{l}-0.0111 \\
(0.646)\end{array}$ \\
\hline \multicolumn{10}{|l|}{ Short-run } \\
\hline$\triangle L O L P_{t-1}$ & $\begin{array}{l}-0.0435^{*} \\
(0.014)\end{array}$ & $\begin{array}{l}-0.00940 \\
(0.715)\end{array}$ & $\begin{array}{l}0.0105 \\
(0.547)\end{array}$ & $\begin{array}{l}-0.0370 \\
(0.250)\end{array}$ & $\begin{array}{l}-0.0659 * * \\
(0.013)\end{array}$ & $\begin{array}{l}-0.0382 \\
(0.158)\end{array}$ & $\begin{array}{l}-0.0386 * * \\
(0.014)\end{array}$ & $\begin{array}{l}-0.0336 * \\
(0.085)\end{array}$ & $\begin{array}{l}0.00553 \\
(0.757)\end{array}$ \\
\hline$\Delta L I N F_{t-1}$ & $\begin{array}{l}-0.00183 \\
(0.575)\end{array}$ & $\begin{array}{l}-0.0295 \\
(0.180)\end{array}$ & $\begin{array}{l}-0.0005 \\
(0.956)\end{array}$ & $\begin{array}{l}0.00822 \\
(0.276)\end{array}$ & $\begin{array}{l}-0.0264 * \\
(0.070)\end{array}$ & $\begin{array}{l}-0.0061 \\
(0.318)\end{array}$ & $\begin{array}{l}0.00324 \\
(0.394)\end{array}$ & $\begin{array}{l}-0.0282^{* *} \\
(0.038)\end{array}$ & $\begin{array}{l}-0.00350 \\
(0.472)\end{array}$ \\
\hline$\Delta L T O_{t-1}$ & $\begin{array}{l}-0.317 \\
(0.220)\end{array}$ & $\begin{array}{l}-0.240 \\
(0.089)\end{array}$ & $\begin{array}{l}-0.101 \\
(0.283)\end{array}$ & $\begin{array}{l}0.0396 \\
(0.639) \\
\end{array}$ & $\begin{array}{l}0.0419 \\
(0.598)\end{array}$ & $\begin{array}{l}0.0689 \\
(0.403)\end{array}$ & $\begin{array}{l}-0.125 \\
(0.272)\end{array}$ & $\begin{array}{l}-0.119 \\
(0.200)\end{array}$ & $\begin{array}{l}-0.0241 \\
(0.714)\end{array}$ \\
\hline$\triangle L U R B_{t-1}$ & $\begin{array}{l}867.6 \\
(0.319)\end{array}$ & $\begin{array}{l}1168.1 \\
(0.355)\end{array}$ & $\begin{array}{l}-1.102^{* *} \\
(0.027)\end{array}$ & $\begin{array}{l}-16.53 \\
(0.130)\end{array}$ & $\begin{array}{l}1.673 \\
(0.820)\end{array}$ & $\begin{array}{l}-0.0417 \\
(0.945)\end{array}$ & $\begin{array}{l}387.7 \\
(0.331)\end{array}$ & $\begin{array}{l}668.2 \\
(0.352)\end{array}$ & $\begin{array}{l}0.0979 \\
(0.844)\end{array}$ \\
\hline $\begin{array}{l}\text { Hausman } \\
\text { test }\end{array}$ & & $\begin{array}{l}0.95 \\
(0.9166)\end{array}$ & $\begin{array}{l}5.08 \\
(0.3695) \\
\end{array}$ & & $\begin{array}{l}2.15 \\
(0.7077) \\
\end{array}$ & $\begin{array}{l}0.68 \\
(0.8593)\end{array}$ & & $\begin{array}{l}1.49 \\
(0.8289)\end{array}$ & $\begin{array}{l}2.35 \\
(0.6582)\end{array}$ \\
\hline Model & & PMG & PMG & & PMG & PMG & & PMG & PMG \\
\hline
\end{tabular}

263 Note. The PMG estimator is accepted under the null hypothesis of the Hausman test, while the MG estimator is accepted under the alternative hypothesis.

265 As shown in Table 6, the long-run finding shows that oil prices impact food prices positively and significantly for all samples. This corresponds to several empirical studies (e.g. Alghalith, 2010; Baumeister and Kilian, 2014; Olayungbo and Hassan, 2016; Taghizadeh-hesary et al., 2019), suggesting that a rising oil price will induce higher food prices in the long-term. Further, we observe that the coefficients of $L O L P$ of oil-exporters are greater than those for oil-importers which indicate the food prices of oil-exporters are rising more than that of oil-importers with

272 exporters will spur more food demand and increase energy consumption costs in the food

273 production process and ultimately lead to higher local food prices. It is also important to note 
the benefits of oil exports. Another phenomenon is that oil prices have a significantly negative short-term influence on oil-exporters' food prices, unlike for oil-importers where this is not significant. The reason for this is that oil-exporters can take short-term measures to mitigate the negative effects on the food system from high oil prices, while oil-importers have greater difficulty in taking effective short-run measures.

The rate of inflation (INF) is similarly affected by food prices for both oil-exporters and oilimporters positively and significantly in the long-term, while the short-term effect insignificant. This finding is in line with Furceri et al. (2016), indicating that inflation has boosted food prices. However, this effect is larger for oil-exporters than oil-importers. Specifically, a $1 \%$ increase in the inflation rate increases food prices in the long-term by $0.049 \%$ for oil-exporters while this change is $0.037 \%$ for the oil-importing group in the long-term. This indicates that prices of food for oil-exporters are more sensitive than for importers.

In addition, the trade openness index (TO) affected negatively and significantly the long-run food prices for all samples. This effect can be explained by the competitiveness of food commodities when MENA countries open up to foreign trade, leading to the further long-term declines in food prices. The short-term coefficient of trade openness was found to be negative and insignificant in the MENA region. The reason may be that it takes a long time for the welfare effect of trade freedom to impact food prices.

The long-run results show that urban population (URB) also affects food prices positively and is statistically significant for the sampled countries. This implies that rural migration to cities within the same country — or between MENA countries - this has resulted in a substantial increase in the urban population thereby depriving labour from the agricultural sector in rural areas. As a consequence, the agricultural sector's performance in these areas has deteriorated, leading to higher food prices. 
For all sample countries, the error correction coefficients (ECTs) terms are statistically significant, negative, and less than one, demonstrating that short-run fluctuations in the system will converge in a long-run relationship. For oil-exporters, the distortions due to food price shocks can be corrected at a speed of 31.4\%. Alternatively, for oil-importers, the speed of longrun equilibrium adjustment is $44.2 \%$ - which is faster than for the oil-exporting group.

To test how robust the estimated outcomes are, this study re-estimated the PMG model by gradually adding variables and the panel OLS results are reported (see Appendix Table A, B, and C). The former results show that as the number of variables increases, the coefficients of most variables fluctuated in a small range, verifying that the estimation results are robust. The latter results indicate that, as expected, most of the variables are correctly signed, proving that the long-run result of PMG estimates is reasonable.

\section{Food prices asymmetrical response to oil prices}

Food prices in MENA countries may have different impact mechanisms in the face of fluctuating oil prices. To explore this asymmetric response, we use panel data samples for country groups and time series for each country to analyse the heterogeneous response of different samples.

\section{(1) Estimation results using panel data}

With the null hypothesis that positive and negative changes are not jointly significant, Wald tests are conducted to investigate the existence of an asymmetry relationship with panel data used for both groups of oil-exporters and oil-importers nations. Table 7 shows that for the entire sample of MENA countries, the null hypothesis is rejected for both short- and long-term, which supports the asymmetrical relationship and implies that oil prices do not have the identical impact on food price as oil prices rise and decrease. From the perspective of country groups, however, the F-statistics of the Wald test are not significant. This result predicts the heterogeneous response within the oil importing and exporting countries groups. 
Table 7 Wald Test for Asymmetry

\begin{tabular}{lllllll}
\hline & \multicolumn{2}{l}{ Oil-exporting countries } & \multicolumn{2}{l}{ Oil-importing countries } & \multicolumn{2}{l}{ MENA countries } \\
\cline { 2 - 7 } & Long-run & Short-run & Long-run & Short-run & Long-run & Short-run \\
\hline Wald Statistic & 0.95 & 1.52 & 0.43 & 1.51 & $3.25^{*}$ & $6.38^{* *}$ \\
& $(0.3301)$ & $(0.2180)$ & $(0.5126)$ & $(0.2190)$ & $(0.0713)$ & $(0.0115)$ \\
\hline Asymmetric Evidence & No & No & No & No & Yes & Yes \\
\hline
\end{tabular}

325

326

327

Note. The null hypothesis of Wald's test that positive and negative changes are not jointly significant. Thus, they do not differ from zero, the alternative is that the changes are jointly significant.

The estimated asymmetric impacts of changes in oil price on food price sample groups is presented in Table 8 using equation (3). First, all equations are estimated using PMG, MG, and DFE estimators, and then choose the most appropriate estimator based on the Hausman test in the last line of Table 8 . The findings show that the null hypothesis is appropriate, which suggests that all groups are consistent with the PMG estimator.

Table 8 Estimation of NARDL Models.

\begin{tabular}{|c|c|c|c|}
\hline Variables & Oil-exporting countries & Oil-importing countries & MENA countries \\
\hline \multicolumn{4}{|l|}{ Long-run } \\
\hline \multirow[t]{2}{*}{$L O L P_{t-1}^{-}$} & $0.373^{* * *}$ & $0.287^{* * *}$ & $0.296^{* * *}$ \\
\hline & $(0.000)$ & $(0.000)$ & $(0.000)$ \\
\hline \multirow{2}{*}{$L O L P^{+}{ }_{t-1}$} & $0.354^{* * *}$ & $0.301^{* * *}$ & $0.302^{* * *}$ \\
\hline & $(0.000)$ & $(0.000)$ & $(0.000)$ \\
\hline \multirow[t]{2}{*}{$L I N F_{t-1}$} & $0.0688^{* *}$ & $0.0373^{* *}$ & 0.0256 \\
\hline & $(0.003)$ & $(0.005)$ & $(0.151)$ \\
\hline \multirow[t]{2}{*}{$L T O_{t-1}$} & $-0.361^{* *}$ & $-0.358^{* * *}$ & $-0.408^{* * *}$ \\
\hline & $(0.032)$ & $(0.000)$ & $(0.000)$ \\
\hline \multirow[t]{2}{*}{$L U R B_{t-1}$} & $2.354^{* * *}$ & $1.992^{* * *}$ & $1.915^{* * *}$ \\
\hline & $(0.000)$ & $(0.000)$ & $(0.000)$ \\
\hline \multirow[t]{2}{*}{ ECT } & $-0.262^{*}$ & -0.175 & $-0.250^{* *}$ \\
\hline & $(0.052)$ & $(0.171)$ & $(0.025)$ \\
\hline \multicolumn{4}{|l|}{ Short-run } \\
\hline \multirow[t]{2}{*}{$\Delta . \mathrm{LOLP}^{+}{ }_{t-1}$} & $-0.0229^{*}$ & -0.0382 & $-0.0494^{* *}$ \\
\hline & $(0.051)$ & $(0.326)$ & $(0.021)$ \\
\hline \multirow[t]{2}{*}{$\Delta . L O L P_{t-1}^{-}$} & $-0.0255^{*}$ & -0.0360 & $-0.0470^{* *}$ \\
\hline & $(0.057)$ & $(0.365)$ & $(0.027)$ \\
\hline \multirow[t]{2}{*}{$\Delta L I N F_{t-1}$} & -0.00333 & 0.0140 & 0.00624 \\
\hline & $(0.458)$ & $(0.220)$ & $(0.241)$ \\
\hline \multirow[t]{2}{*}{$\Delta L T O_{t-1}$} & -0.257 & 0.0439 & -0.183 \\
\hline & $(0.141)$ & $(0.619)$ & $(0.265)$ \\
\hline \multirow[t]{2}{*}{$\Delta L U R B_{t-1}$} & 754.2 & $-18.67^{*}$ & 460.0 \\
\hline & $(0.317)$ & $(0.097)$ & $(0.328)$ \\
\hline \multirow[t]{2}{*}{ Hausman test } & 0.37 & 3.63 & 0.55 \\
\hline & $(0.9961)$ & $(0.6046)$ & $(0.2303)$ \\
\hline Model & PMG & PMG & PMG \\
\hline
\end{tabular}

333 For the MENA sample, the short-term asymmetrical parameters of a? ?LOLP $P_{t-1}^{+}$and 
the short-term, whether oil prices increase or decrease. One possible reason is that in the shortterm, governments provide timely food subsidies and other measures to stabilize prices. However, the long-term asymmetric parameters (0.296 and 0.302) are positively significant at the $1 \%$ level, which indicates, whether oil prices rise or fall, food prices always rise. This confirms that continuing food price rises is inevitable over the long-term even though it will decline in the short-term. Another observed phenomenon is that when oil prices rise, food prices rise faster than the corresponding decline when oil prices fall. This finding indicates that when the international oil price rises, it exerts more pressure on the domestic food price.

Error correction coefficients (ECTs) terms are negatively significant for the samples of oilexporting and MENA countries that support a long-term convergence. When a short-term deviation is caused by shocks in food prices, the adjustment to the long-run equilibrium in the long-term is $26.2 \%$ and $25 \%$ in oil-exporting and MENA countries, respectively. Alternatively, the coefficient of ECT for oil-importing countries is shown to be negative but statistically insignificant indicating no convergence in the long-run relationship.

\section{(2) Estimation results using time series}

We estimate the non-linear effects of oil price on each country's food price by employing time series for the two groups (oil-exporters and oil-importers) following the non-linear ARDL model. The Wald test results for asymmetries are summarized in Table 9.

Table 9 Wald Test for Asymmetry in MENA countries

\begin{tabular}{lllll}
\hline \multirow{2}{*}{ Country } & \multicolumn{2}{c}{ Wald Statistic } & \multicolumn{2}{c}{ Asymmetric Evidence } \\
\cline { 2 - 5 } Oil-exporting countries & Long-run & Short-run & Long-run & Short-run \\
Algeria & $48.39^{* * *}$ & 0.07652 & Yes & No \\
& $(0.000)$ & $(0.788)$ & & \\
Bahrain & $32.93^{* * *}$ & 0.3956 & Yes & No \\
Iraq & $(0.000)$ & $(0.543)$ & & No \\
& $15.78^{* *}$ & 2.032 & Yes & No \\
Kuwait & $(0.003)$ & $(0.184)$ & & No \\
Oman & 2.148 & 7.584 & No & \\
\multirow{2}{*}{ Qatar } & $(0.173)$ & $(0.979)$ & Yes & No \\
& $13.72^{* *}$ & 0.0148 & &
\end{tabular}




\begin{tabular}{|c|c|c|c|c|}
\hline Saudi Arabia & 0.08213 & 0.4131 & No & No \\
\hline UAE & $\begin{array}{l}(0.780) \\
0.7371 \\
(0.411)\end{array}$ & $\begin{array}{l}(0.535) \\
1.64 \\
(0.229)\end{array}$ & No & No \\
\hline \multicolumn{5}{|c|}{ Oil-importing countries } \\
\hline Egypt & $\begin{array}{l}529.5 * * * \\
(0.000)\end{array}$ & $\begin{array}{l}6.211 * * \\
(0.032)\end{array}$ & Yes & Yes \\
\hline Jordan & $\begin{array}{l}31.55 * * * \\
(0.000)\end{array}$ & $\begin{array}{l}0.2005 \\
(0.664)\end{array}$ & Yes & No \\
\hline Lebanon & $\begin{array}{l}57.7 * * * \\
(0.000)\end{array}$ & $\begin{array}{l}1.31 \\
(0.279)\end{array}$ & Yes & No \\
\hline Morocco & $\begin{array}{l}87.09 * * * \\
(0.000)\end{array}$ & $\begin{array}{l}0.0010 \\
(0.975)\end{array}$ & Yes & No \\
\hline Tunisia & $\begin{array}{l}0.2471 \\
(0.630)\end{array}$ & $\begin{array}{l}0.2482 \\
(0.629)\end{array}$ & No & No \\
\hline $\begin{array}{l}\text { West Bank } \\
\& \text { Gaza }\end{array}$ & $\begin{array}{l}8.194 * * \\
(0.017)\end{array}$ & $\begin{array}{l}0.3595 \\
(0.562)\end{array}$ & Yes & No \\
\hline
\end{tabular}

354

355

The asymmetry test findings for oil-exporting group —including Algeria, Bahrain, Iraq, Oman, and Qatar-indicated that the Wald test F-statistics are significant in the long-term, suggesting that asymmetrical influence exists in those countries. Alternatively, economies such as Kuwait, Saudi Arabia, and the United Arab Emirates have rejected the null hypothesis regarding the existence of asymmetric linkage in the short- and long-term, which indicates that the oil-food prices relationship is not asymmetric. This evidence supports our observations of the cumulative effects of oil price on food price (see Appendix Figure A), where the asymmetry line shows that food prices in Kuwait, Saudi Arabia, and the UAE do not react differently to shocks in the oil price—whether increasing or decreasing.

Except for Tunisia, all oil-importers pass the long-term Wald test at 5\% significance level, indicating how asymmetric the changes in the price of oil are influencing long-term food price. The asymmetry line implies that the impact of oil price on food price in Egypt, Jordan, Lebanon, Morocco, the West Bank, and Gaza is not identical for either a rise or decline in oil price, as seen in the plots of the cumulative effects of oil price on food price (see Appendix Figure B).

The long-run asymmetric effects for each MENA country are shown in Table 10. For the oilexporting group, the results show that the coefficients associated with increases in the oil price positively affect food prices. Specifically, an increase of $1 \%$ in positive oil price changes causes 
an increase of between $0.24 \%$ and $0.59 \%$ in food prices. Nevertheless, the coefficients related

to decreases in the oil price negatively affect food prices in Iraq, whereas in Algeria, Bahrain,

373 Oman, and Qatar these are insignificant. For oil-importing nations, the outcomes also indicate that food prices are positively influenced by the increasing oil price changes. A $1 \%$ rise in oil prices results in a $0.12 \%$ to $0.40 \%$ increase in food prices. However, the coefficients of oil price reductions have been found to be mixed. Egypt and Lebanon are positively affected, while Jordan is negatively affected, and the impact on Morocco, the West Bank and Gaza are insignificant.

Table 10 Long-run asymmetric effects

\begin{tabular}{|c|c|c|c|c|c|c|c|c|}
\hline \multicolumn{9}{|c|}{ Oil exporting countries } \\
\hline & Algeria & Bahrain & \multirow{2}{*}{$\begin{array}{l}\text { Iraq } \\
0.586 * * * \\
(0.000)\end{array}$} & Kuwait & Oman & Qatar & Saudi Arabia & UAE \\
\hline$L O L P^{+}{ }_{t-1}$ & $\begin{array}{l}0.259 * * \\
(0.014)\end{array}$ & $\begin{array}{l}0.239 * * \\
(0.039)\end{array}$ & & - & $\begin{array}{l}0.379 * * * \\
(0.000)\end{array}$ & $\begin{array}{l}0.338 * * \\
(0.003)\end{array}$ & - & - \\
\hline$L O L P^{-}{ }_{t-1}$ & $\begin{array}{l}0.148 \\
(0.291)\end{array}$ & $\begin{array}{l}-0.015 \\
(0.914)\end{array}$ & $\begin{array}{c}-0.309 * * \\
(0.009)\end{array}$ & - & $\begin{array}{l}-0.161 \\
(0.201)\end{array}$ & $\begin{array}{l}-0.159 \\
(0.283)\end{array}$ & - & - \\
\hline \multicolumn{9}{|c|}{ Oil importing countries } \\
\hline & Egypt & \multicolumn{2}{|c|}{ Jordan } & Lebanon & Morocco & Tunisia & West Bank \& & Gaza \\
\hline$L O L P^{+} t-1$ & $\begin{array}{l}0.255^{* * * *} \\
(0.001)\end{array}$ & \multicolumn{2}{|c|}{$\begin{array}{l}0.403 * * * \\
(0.000)\end{array}$} & $\begin{array}{l}0.214 * * \\
(0.003)\end{array}$ & $\begin{array}{l}0.124 * * * \\
(0.000)\end{array}$ & - & \multicolumn{2}{|l|}{$\begin{array}{l}0.298 * * * \\
(0.000)\end{array}$} \\
\hline$L O L P^{-} t-1$ & $\begin{array}{l}0.399 * * * \\
(0.000)\end{array}$ & \multicolumn{2}{|c|}{$\begin{array}{c}-0.173^{*} \\
(0.067)\end{array}$} & $\begin{array}{l}0.153^{*} \\
(0.097)\end{array}$ & $\begin{array}{l}0.039 \\
(0.296)\end{array}$ & - & \multicolumn{2}{|l|}{$\begin{array}{c}-0.143 \\
(0.140)\end{array}$} \\
\hline
\end{tabular}
countries' different economic status, the asymmetric impacts of fluctuations in oil prices on the food price varies. In general, our conclusion is that when oil prices rise, the food prices also rise; but when oil prices drop, food prices do not always decrease. This also proves that, as a necessary commodity, the price of food is sticky — it does not fall easily.

\section{Conclusions and policy implications}

The linear and nonlinear panel ARDL models are used in this paper to investigate the symmetrical and asymmetrical relationship between world oil prices and local food prices for the MENA region from 2000 to 2020. Findings from the symmetric linear ARDL model show that oil prices have a long-run positive and significant impact on food prices for oil-exporting 
and importing MENA nations. The positive impact is larger for oil-exporters than for oilimporters. This outcome concludes oil prices have a greater influence on increases in food prices for those economies that export oil at high prices. This results in increased costs for imported food due to the higher energy cost needed to produce food commodities in the country of origin. Furthermore, we found that the inflation rate and urban population affect positively and significantly on food prices for oil-exporters and importers groups, while trade openness is negative and significant in relation to food prices. These results suggest that expanding trade openness can help these countries source cheaper food resources. Additionally, reducing inflation and controlling the scale of urbanization will foster agricultural development and ensure an adequate food supply.

For the entire sample from the MENA region, outcomes indicate that the oil price effect on food price is asymmetrical in the short- and long-term although this effect is insignificant for the oilexporters and importers groups. This finding follows Meyer et al. (2018) and Ibrahim (2015). However, the short-term asymmetric effect was negative, while this was found to be positive in the long-term, indicating that — whether oil prices rise or fall—food prices always rise. These results indicate that food products price is sticky: once food prices rise, it is harder to reduce them. Therefore, policymakers should take measures to improve agricultural labour productivity, increase the supply capacity of agricultural products, and develop renewable energy sources (such as photovoltaic cells) to eliminate the dependence of agriculture on oil. For the MENA region, developing biomass energy is discouraged to prevent the reduction in available agricultural land. Thus, while developing biomass energy, the government-should reasonably assess its potential impact on agricultural land and food supply.

Regarding the non-linear ARDL results for each country using time series, we found an absence of asymmetrical behaviour for nations including Kuwait, Saudi Arabia, and the UAE from the oil-exporting group, and Tunisia from the oil-importing group. Except those countries, others 
have the asymmetrical effects in food prices responses to oil prices in the long-term. Oil prices

\section{Appendix:} have a major impact on countries such as Iraq and Jordan, and food price tracked oil price fluctuations. To maintain the stability of food prices, these countries need to make countercyclic adjustments; when the oil price is expected to rise, they should stockpile a large amount of food, and when the oil price is expected to fall, they should sell food. For countries such as Egypt and Lebanon, The rate of increase in food prices fluctuates with rising oil prices; hence, these governments need to establish long-term food price stability mechanisms-increasing food production, establishing a stable international food trading partner and other policies regardless of how oil prices fluctuate. Additionally, for countries such as Algeria and Bahrain which are seriously affected by increases in the oil price — but not by its decline - they need to stockpile more agricultural products before forecasting higher oil prices.

As one of the global regions with insufficient food supply, food price stability in the MENA region is an important guarantee of food security. First, MENA governments should review their agricultural policies by providing incentives and implementing effective mechanisms to increase domestic production to avoid the effects of high food prices that result from energy price fluctuations; second, as most MENA agricultural resources (whether water or arable land) are located in oil-importing countries (characterized by a scarcity of financial resources) while oil-exporters have enormous oil wealth (matched by a scarcity of arable land and water) cooperation should be strengthened between countries to stabilize oil and food prices. Third, according to the differentiated symmetrical and asymmetrical mechanisms of food and oil prices, MENA countries should establish specific coping strategies. For countries with a relatively large impact on international oil prices, an early warning mechanism could mitigate price spikes in food and oil.

Table A The estimated results of the pooled mean group and panel OLS for oil-exporting countries 


\begin{tabular}{|c|c|c|c|c|c|}
\hline \multicolumn{6}{|l|}{ Long-run } \\
\hline$L O L P_{t-1}$ & $\begin{array}{l}0.578 * * * \\
(0.000)\end{array}$ & $\begin{array}{l}0.498 * * * \\
(0.000)\end{array}$ & $\begin{array}{l}0.452 * * * \\
(0.000)\end{array}$ & $\begin{array}{l}0.334 * * * \\
(0.000)\end{array}$ & $\begin{array}{l}0.283 * * \\
(0.008)\end{array}$ \\
\hline$L I N F_{t-1}$ & & $\begin{array}{l}0.0929 * \\
(0.088)\end{array}$ & $\begin{array}{l}0.112 * * \\
(0.037)\end{array}$ & $\begin{array}{l}0.0499 * * \\
(0.012)\end{array}$ & $\begin{array}{l}-0.0541 * * \\
(0.023)\end{array}$ \\
\hline$L T O_{t-1}$ & & & $\begin{array}{l}0.0431 \\
(0.876)\end{array}$ & $\begin{array}{l}-0.357 * * \\
(0.016)\end{array}$ & $\begin{array}{l}-0.311 \\
(0.335)\end{array}$ \\
\hline$L U R B_{t-1}$ & & & & $\begin{array}{l}2.385 * * * \\
(0.000)\end{array}$ & $\begin{array}{l}3.502 * * \\
(0.002)\end{array}$ \\
\hline ECT & $\begin{array}{l}-0.109 * * * \\
(0.000) \\
\end{array}$ & $\begin{array}{l}-0.0864 * * * \\
(0.000)\end{array}$ & $\begin{array}{l}-0.0833 * * * \\
(0.000)\end{array}$ & $\begin{array}{l}-0.314^{*} \\
(0.062)\end{array}$ & \\
\hline Short -run & & & & & \\
\hline$\Delta . L O L P_{t-1}$ & $\begin{array}{l}-0.0135 \\
(0.632)\end{array}$ & $\begin{array}{l}-0.00907 \\
(0.721)\end{array}$ & $\begin{array}{l}-0.00223 \\
(0.870)\end{array}$ & $\begin{array}{l}-0.0435 * * \\
(0.014)\end{array}$ & \\
\hline$\Delta . L^{\prime N} F_{t-1}$ & & $\begin{array}{l}0.00299 \\
(0.622)\end{array}$ & $\begin{array}{l}0.00122 \\
(0.821)\end{array}$ & $\begin{array}{l}-0.00183 \\
(0.575)\end{array}$ & \\
\hline$\Delta_{. L T O} t-1$ & & & $\begin{array}{l}-0.0616 \\
(0.319)\end{array}$ & $\begin{array}{l}-0.317 \\
(0.220)\end{array}$ & \\
\hline$\Delta_{L U R} B_{t-1}$ & & & & $\begin{array}{l}867.6 \\
(0.319) \\
\end{array}$ & \\
\hline
\end{tabular}

440

441 Table B The estimated results of the pooled mean group and panel OLS for oil-importing countries

\begin{tabular}{|c|c|c|c|c|c|c|}
\hline \multirow{2}{*}{\multicolumn{7}{|c|}{ Long-run }} \\
\hline & & & & & & \\
\hline \multirow[t]{2}{*}{$L O L P_{t-1}$} & $0.594 * * *$ & $0.738 * *$ & $0.486 * * *$ & $0.269 * * *$ & $0.321 * *$ & 444 \\
\hline & $(0.000)$ & $(0.039)$ & $(0.000)$ & $(0.000)$ & $(0.022)$ & 445 \\
\hline \multirow{2}{*}{$L I N F_{t-1}$} & & $1.633 * *$ & $0.0774 *$ & $0.0375 *$ & 0.139 & \\
\hline & & $(0.002)$ & $(0.064)$ & $(0.062)$ & $(0.332)$ & 446 \\
\hline \multirow[t]{2}{*}{$L T O_{t-1}$} & & & $-0.825 * * *$ & $-0.416 * * *$ & -0.841 & \\
\hline & & & $(0.000)$ & $(0.000)$ & $(0.106)$ & 447 \\
\hline \multirow[t]{2}{*}{$L U R B_{t-1}$} & & & & $2.035 * * *$ & 2.874 & \\
\hline & & & & $(0.000)$ & $(0.112)$ & 448 \\
\hline \multirow[t]{2}{*}{$E C T$} & $-0.0566^{*}$ & - & -0.0606 & -0.167 & & 440 \\
\hline & $(0.048)$ & $\begin{array}{l}0.0241 * * * \\
(0.001)\end{array}$ & $(0.423)$ & $(0.177)$ & & \\
\hline \multicolumn{7}{|l|}{ Short-run } \\
\hline$\Delta . L O L P_{t-1}$ & $\begin{array}{l}-0.0277 * \\
(0.069)\end{array}$ & $\begin{array}{l}-0.0416^{*} \\
(0.050)\end{array}$ & $\begin{array}{l}-0.0465 \\
(0.102)\end{array}$ & $\begin{array}{l}-0.0370 \\
(0.250)\end{array}$ & & \\
\hline$\Delta . \operatorname{LINF}_{t-1}$ & & $\begin{array}{l}-0.00128 \\
(0.881)\end{array}$ & $\begin{array}{l}0.0146 \\
(0.241)\end{array}$ & $\begin{array}{l}0.00822 \\
(0.276)\end{array}$ & & \\
\hline$\Delta . L T O_{t-1}$ & & & $\begin{array}{l}0.0200 \\
(0.790)\end{array}$ & $\begin{array}{l}0.0396 \\
(0.639)\end{array}$ & & \\
\hline $\operatorname{D.LURB}_{t-1}$ & & & & $\begin{array}{l}-16.53 \\
(0.130)\end{array}$ & & \\
\hline
\end{tabular}

449 Table C The estimated results of the pooled mean group and panel OLS for MENA countries

\begin{tabular}{|c|c|c|c|c|c|}
\hline \multicolumn{5}{|c|}{ Pooled mean group } & \multirow[t]{2}{*}{ panel OLS } \\
\hline \multicolumn{5}{|l|}{ Long-run } & \\
\hline \multirow[t]{2}{*}{$L O L P_{t-1}$} & $0.584^{* * *}$ & $0.525^{* * * *}$ & $0.524^{* * * *}$ & $0.274^{* * * *}$ & $0.295^{* * *}$ \\
\hline & $(0.000)$ & $(0.000)$ & $(0.000)$ & $(0.000)$ & $(0.000)$ \\
\hline \multirow[t]{2}{*}{$L I N F_{t-1}$} & & $0.122^{* *}$ & $0.176^{* *}$ & $0.0464^{* *}$ & 0.00979 \\
\hline & & $(0.016)$ & $(0.005)$ & $(0.002)$ & $(0.835)$ \\
\hline \multirow[t]{2}{*}{$L T O_{t-1}$} & & & -0.0624 & $-0.369^{* * *}$ & $-0.626^{*}$ \\
\hline & & & $(0.792)$ & $(0.000)$ & $(0.051)$ \\
\hline \multirow[t]{2}{*}{$L U R B_{t-1}$} & & & & $2.081^{* * * *}$ & $3.227^{* * * *}$ \\
\hline & & & & $(0.000)$ & $(0.000)$ \\
\hline
\end{tabular}




\begin{tabular}{lllll}
$E C T$ & $-0.0863^{* * *}$ & $-0.0636^{* * *}$ & $-0.0572^{* * *}$ & $-0.244^{* *}$ \\
& $(0.000)$ & $(0.000)$ & $(0.000)$ & $(0.015)$ \\
\hline Short -run & & & & \\
\hline A.LOLP $t-1$ & -0.0196 & -0.0212 & -0.0156 & $-0.0386^{* *}$ \\
& $(0.247)$ & $(0.195)$ & $(0.250)$ & $(0.014)$ \\
S.LINF $_{t-1}$ & & 0.00730 & 0.00579 & 0.00324 \\
& & $(0.201)$ & $(0.328)$ & $(0.394)$ \\
A.LTO & & & -0.0393 & -0.125 \\
& & & $(0.307)$ & $(0.272)$ \\
A.LURB & & & & 387.7 \\
& & & & $(0.331)$ \\
\hline
\end{tabular}

Figure A The cumulative effect of oil price on food price in oil-exporters group

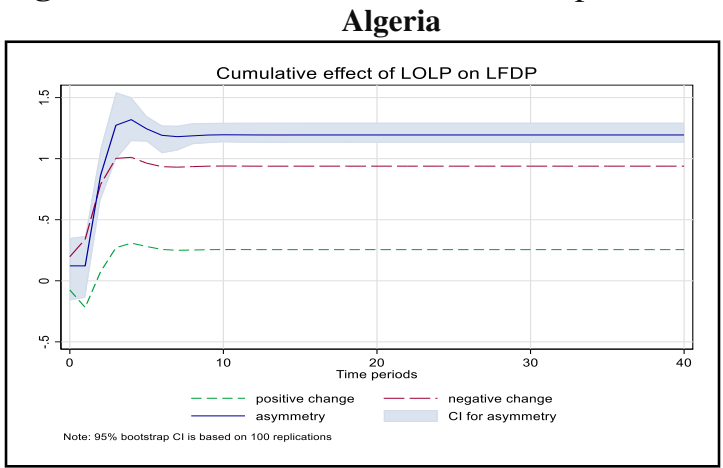

\section{Algeria}
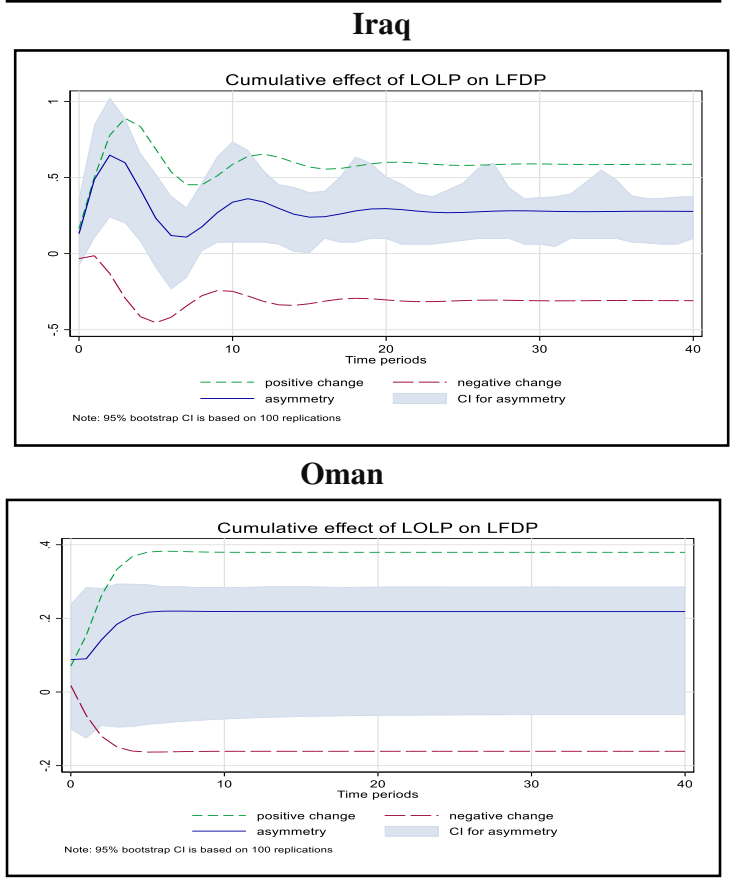

457

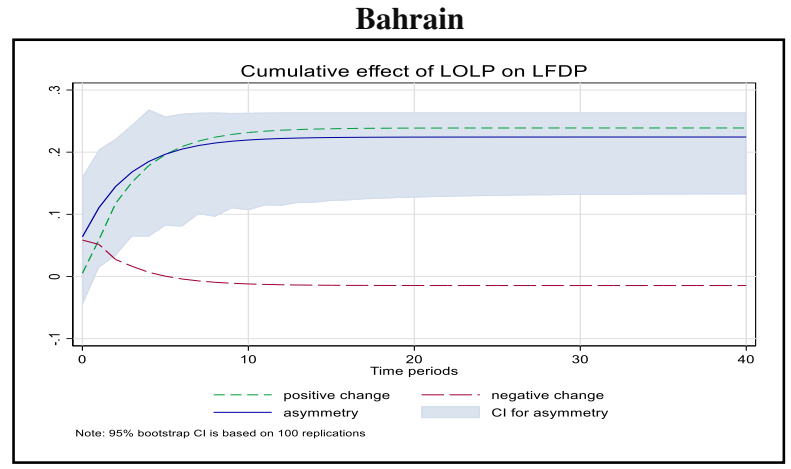

Kuwait

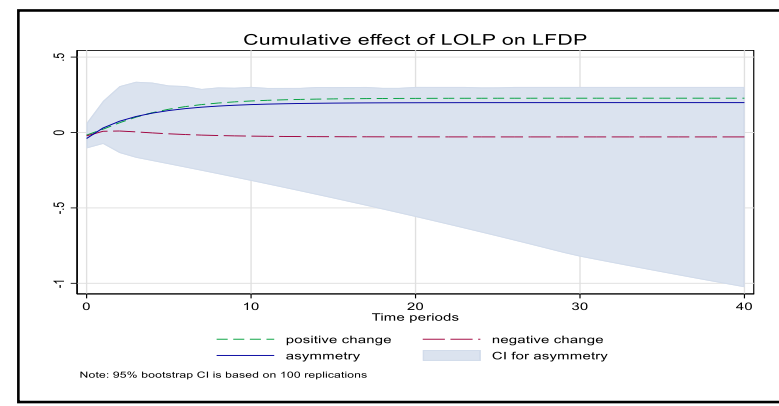

Qatar
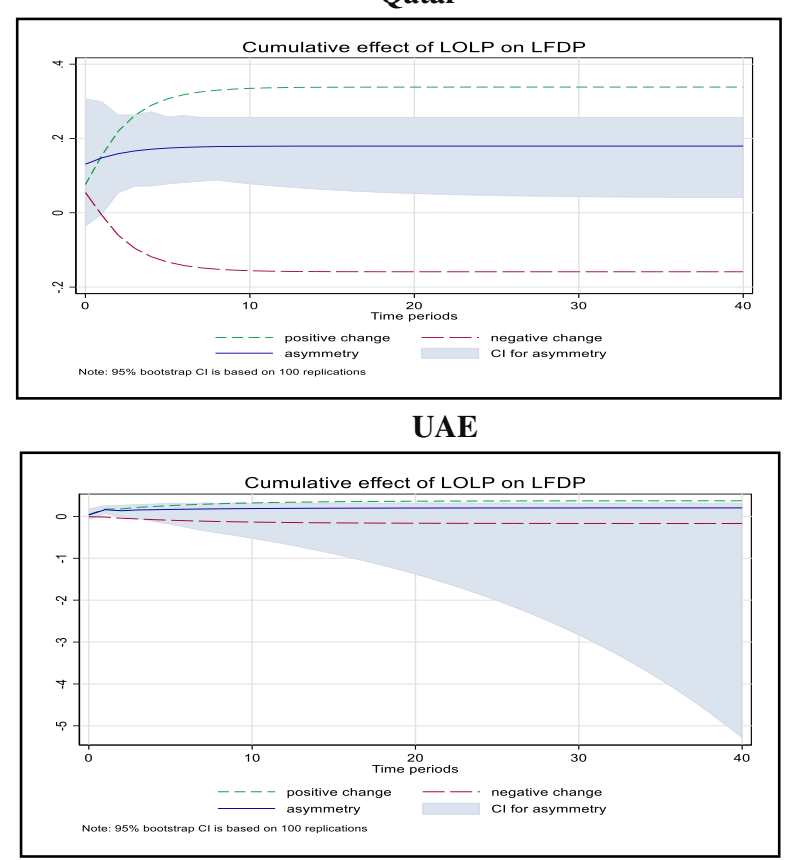
Figure B The cumulative effect of oil price on food price in oil-importers group

460

461

462

463

464

465

466

467

468

469

470

471

472

473

474
Egypt

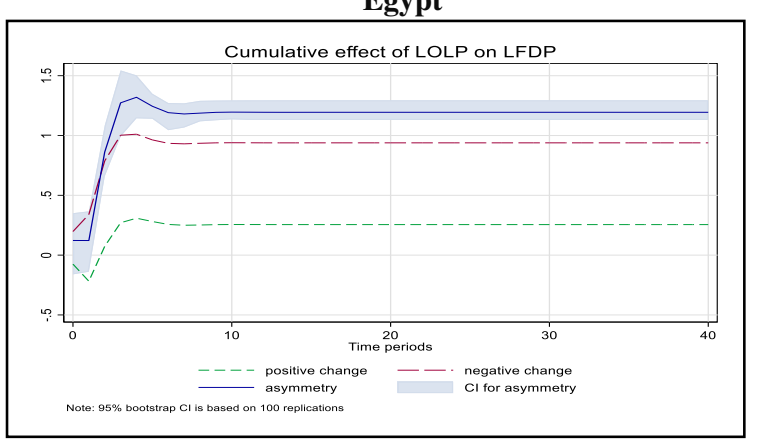

Lebanon

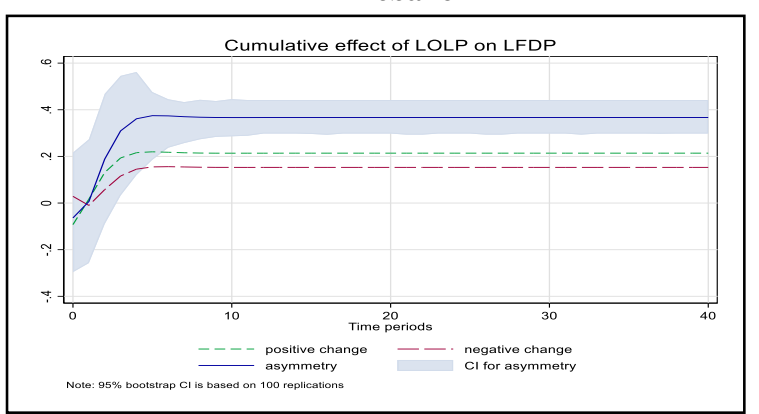

Tunisia

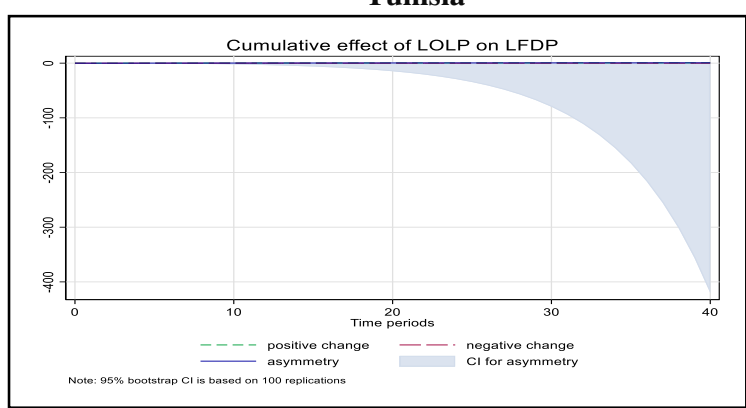

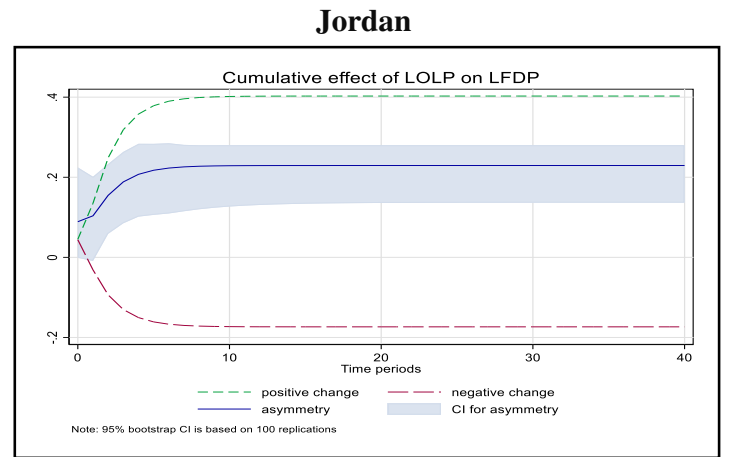

Morocco

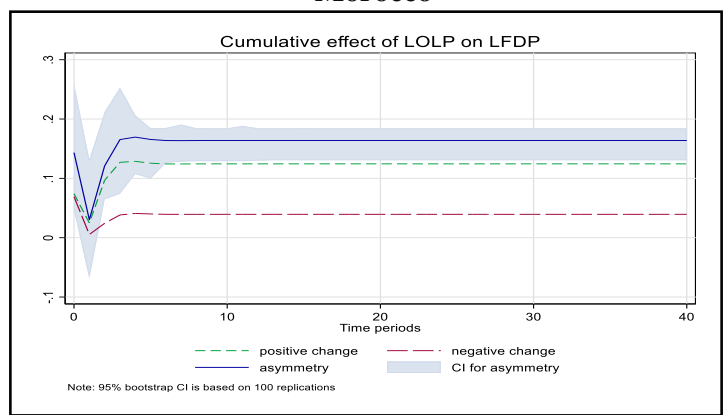

West Bank \& Gaza

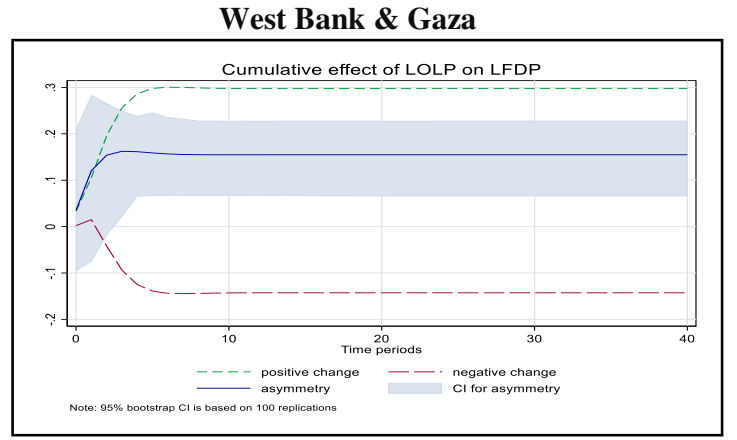

\section{Acknowledgements:}

The authors are thankful to the editors and the anonymous reviews for their valuable comments and suggestions on this paper. This work was supported by the Beijing Natural Science Foundation of China (9192006), the National Natural Science Foundation of China (72073008, 71704047), the Science Foundation of Ministry of Education of China (17YJC790015), Capital Circulation Research Base of China (JD-ZD-2021-003), and the Science and Technology Innovation Service Ability-Beijing Technology and Business University Cultivation Funds of Outstanding Youth Scholars (19008020111) for their financial support.

\section{Authors contributions:}


475 Conceptualization, methodology, funding acquisition: Hadj Cherif Houda, Guohua Ni;

476 Analysis and interpretation: Hadj Cherif Houda, Zhenling Chen;

477 Writing, review and editing: Hadj Cherif Houda, Zhenling Chen;

478 Final approval of the article: Zhenling Chen; Guohua Ni

479 Overall responsibility: Hadj Cherif Houda, Zhenling Chen, Guohua Ni.

480 Zhenling Chen, Guohua Ni contributed equally to this work and share the corresponding author.

481 Data availability of data and materials:

482 All data generated or analyzed during this study are included in this published article.

483 Compliance with ethical standards

484 Ethical approval: Not applicable.

485 Consent to participate: Not applicable.

486 Consent to publish: Written informed consent for publication was obtained from all 487 participants.

488 Competing interests: The authors declare that they have no competing interest.

489

490 References:

491 Alghalith, M., 2010. The interaction between food prices and oil prices. Energy Econ. 32,

492 1520-1522. https://doi.org/10.1016/j.eneco.2010.08.012

493

Apergis, N., El-Montasser, G., Sekyere, E., Ajmi, A.N., Gupta, R., 2014. Dutch disease effect of oil rents on agriculture value added in Middle East and North African (MENA) countries. Energy Econ. 45, 485-490. https://doi.org/10.1016/j.eneco.2014.07.025

Baumeister, C., Kilian, L., 2014. Do oil price increases cause higher food prices? Econ. 
Bellakhal, R., Ben Kheder, S., Haffoudhi, H., 2019. Governance and renewable energy investment in MENA countries:How does trade matter? Energy Econ. 84, 104541. https://doi.org/10.1016/j.eneco.2019.104541

Chen, D., Gummi, U.M., Umar, A.S., 2019. The review on the link between food and oil markets in the view of price dynamics. Am. J. Ind. Bus. Manag. 09, 1890-1900. https://doi.org/10.4236/ajibm.2019.99122

Chen, S., Kuo, H., Chen, C., 2010. Modeling the relationship between the oil price and global food prices. Appl. Energy 87, 2517-2525. https://doi.org/10.1016/j.apenergy.2010.02.020

Ciaian, P., Kancs, A., 2011. Interdependencies in the energy-bioenergy-food price systems: A cointegration analysis. Resour. Energy Econ. 33, 326-348. https://doi.org/10.1016/j.reseneeco.2010.07.004

Dalheimer, B., Herwartz, H., Lange, A., 2021. The threat of oil market turmoils to food price stability in Sub-Saharan Africa. Energy Econ. 93, 105029. https://doi.org/https://doi.org/10.1016/j.eneco.2020.105029

Ek Fälth, H., Atsmon, D., Reichenberg, L., Verendel, V., 2021. MENA compared to Europe: The influence of land use, nuclear power, and transmission expansion on renewable electricity system costs. Energy Strateg. Rev. 33, 100590. https://doi.org/10.1016/j.esr.2020.100590

Engle, R.F., Granger, C.W.J., 1987. Co-integration and error correction:Representationestimation, and testing. Econometrica 55, 251-276.

Esmaeili, A., Shokoohi, Z., 2011. Assessing the effect of oil price on world food prices: Application of principal component analysis. Energy Policy 39, 1022-1025. https://doi.org/10.1016/j.enpol.2010.11.004 
Furceri, D., Loungani, P., Simon, J., Wachter, S.M., 2016. Global food prices and domestic inflation: Some cross-country evidence. Oxf. Econ. Pap. 68, 665-687. https://doi.org/10.1093/oep/gpw016

Gardebroek, C., Hernandez, M.A., 2013. Do energy prices stimulate food price volatility? Examining volatility transmission between US oil, ethanol and corn markets. Energy Econ. 40, 119-129. https://doi.org/10.1016/j.eneco.2013.06.013

Gohin, A., Chantret, F., 2010. The long-run impact of energy prices on world agricultural markets : The role of macro-economic linkages. Energy Policy 38, 333-339. https://doi.org/10.1016/j.enpol.2009.09.023

Ibrahim, M.H., 2015. Oil and food prices in Malaysia: A nonlinear ARDL analysis. Agric. Food Econ. 3, 0-14. https://doi.org/10.1186/s40100-014-0020-3

Johansen, S., Juselius, K., 1992. Testing structural hypotheses in a multivariate cointegration analysis of the PPP and the UIP for UK. J. Econom. 53, 211-244.

Kassouri, Y., Altıntaş, H., 2020. Human well-being versus ecological footprint in MENA countries: A trade-off? J. Environ. Manage. 263, 110405. https://doi.org/10.1016/j.jenvman.2020.110405

Kun, S., Qi, X., Nee, Y., 2015. A comparative study on the effects of oil price changes on inflation. Procedia Econ. Financ. 26, 630-636. https://doi.org/10.1016/S22125671(15)00800-X

Meyer, D.F., Sanusi, K.A., Hassan, A., 2018. Analysis of the asymmetric impacts of oil prices on food prices in oil-exporting developing countries. J. Int. Stud. 11, 82-94. https://doi.org/10.14254/2071-8330.2018/11-3/7

Mokni, K., Ben-Salha, O., 2020. Asymmetric causality in quantiles analysis of the oil-food nexus since the 1960s. Resour. Policy 69, 101874. https://doi.org/https://doi.org/10.1016/j.resourpol.2020.101874 
Nwoko, I.C., Aye, G.C., Asogwa, B.C., 2016. Oil price and food price volatility dynamics: The case of Nigeria. Cogent Food Agric. 2, 1142413. https://doi.org/10.1080/23311932.2016.1142413

Olayungbo, D., Hassan, W., 2016. Effects of oil price on food prices in developing oil exporting countries: a panel autoregressive distributed lag analysis. OPEC Energy Rev. 40, 397-411. https://doi.org/10.1111/opec.12090

Pal, D., Mitra, S.K., 2018. Interdependence between crude oil and world food prices: A detrended cross correlation analysis. Phys. A Stat. Mech. its Appl. 492, 1032-1044. https://doi.org/10.1016/j.physa.2017.11.033

Pal, D., Mitra, S.K., 2016. Asymmetric oil product pricing in India: Evidence from a multiple threshold nonlinear ARDL model. Econ. Model. 59, 314-328. https://doi.org/https://doi.org/10.1016/j.econmod.2016.08.003

Pesaran, M.H., 2007. A simple panel unit root test in the Presence of cross-section dependence. J. Appl. Econom. 312, 265-312. https://doi.org/10.1002/jae

Pesaran, M.H., Shin, Y., Smith, R.J., 2001. Bounds testing approaches to the analysis of level relationships. J. Appl. Econom. 16, 289-326.

Pesaran, M.H., Shin, Y., Smith, R.P., 1999. Pooled mean group estimation of dynamic heterogeneous panels. J. Am. Stat. Assoc. 94, 621-643.

Pesaran, M.H., Smith, R., 1995. Estimating long-run relationships from dynamic heterogeneous panels. J. Econom. 68, 79-113.

Reboredo, J.C., 2012. Do food and oil prices co-move? Energy Policy 49, 456-467. https://doi.org/10.1016/j.enpol.2012.06.035

Salisu, A.A., Isah, K.O., 2017. Revisiting the oil price and stock market nexus : A nonlinear Panel ARDL approach. Econ. Model. 66, 258-271. https://doi.org/10.1016/j.econmod.2017.07.010 
572 Sarwar, M.N., Hussain, H., Maqbool, M.B., 2020. Pass through effects of oil price on food and non-food prices in Pakistan: A nonlinear ARDL approach. Resour. Policy 69, 101876. https://doi.org/https://doi.org/10.1016/j.resourpol.2020.101876

575

576

577

578

579

580
Shin, Y., Yu, B., Greenwood-Nimmo, M., 2014. Modelling asymmetric cointegration and dynamic multipliers in a nonlinear ARDL framework. Festschrift Honor Peter Schmidt 44, 281-314. https://doi.org/10.2139/ssrn.1807745

Taghizadeh-hesary, F., Rasoulinezhad, E., Yoshino, N., 2019. Energy and food security : Linkages through price volatility. Energy Policy 128, 796-806. 

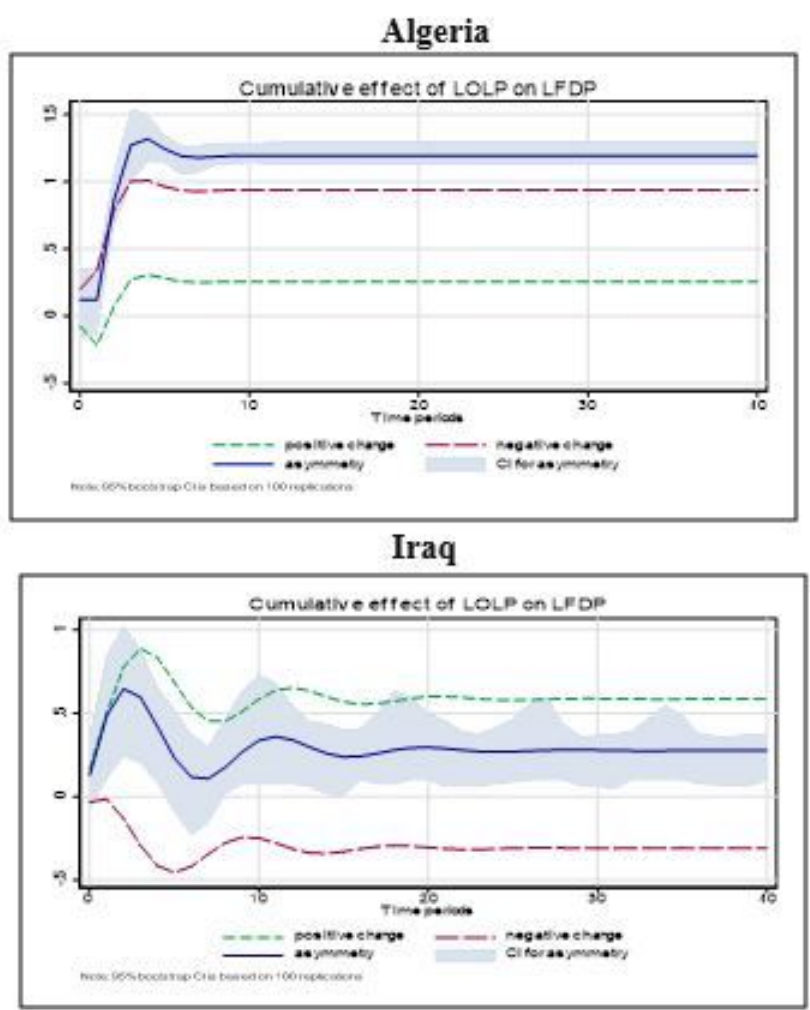

Oman

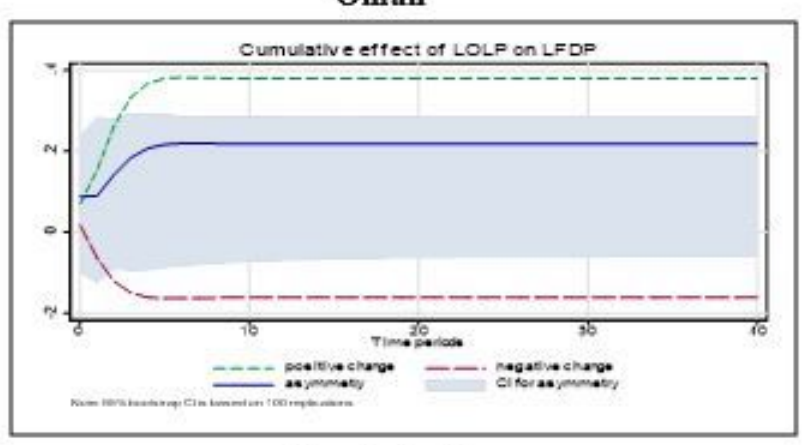

Saudi Arabia

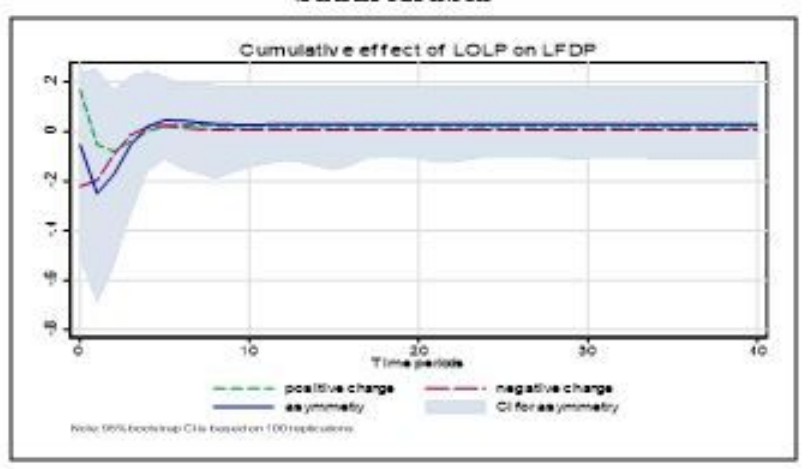

Bahrain

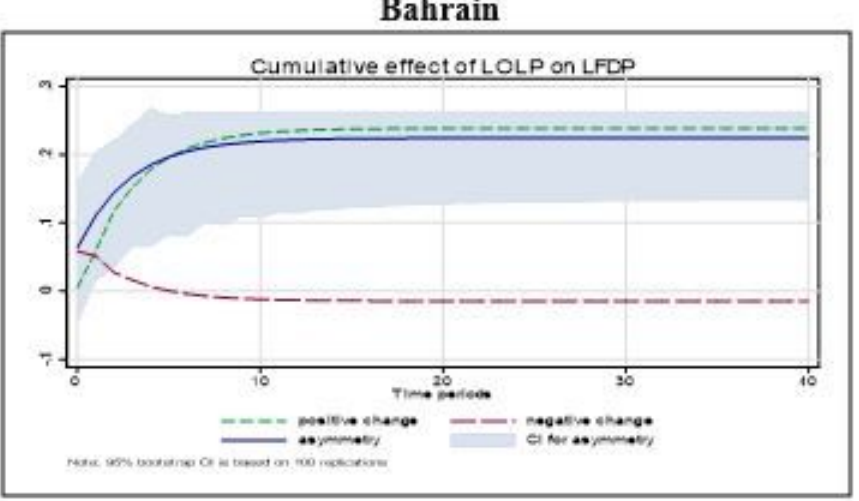

Kuwait

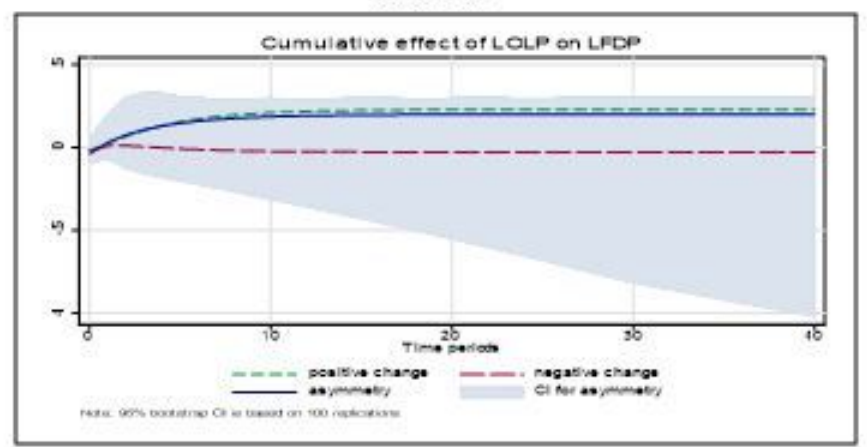

Qatar

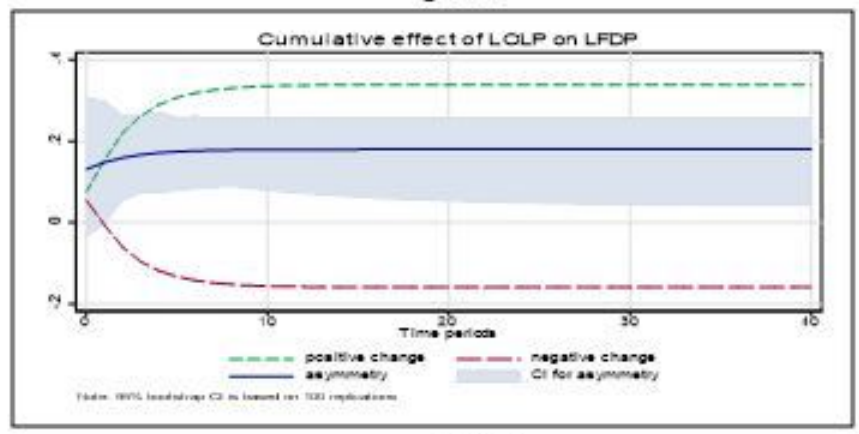

UAE

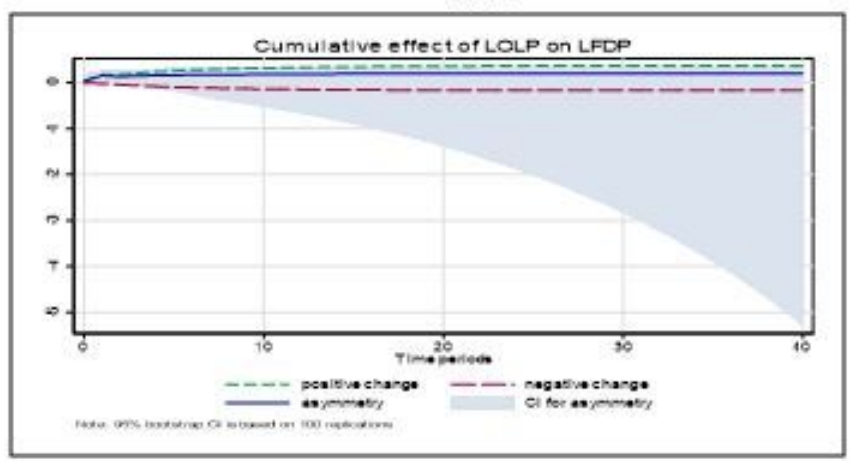

\section{Figure 1}

The cumulative effect of oil price on food price in oil-exporters group 


\section{Egypt}

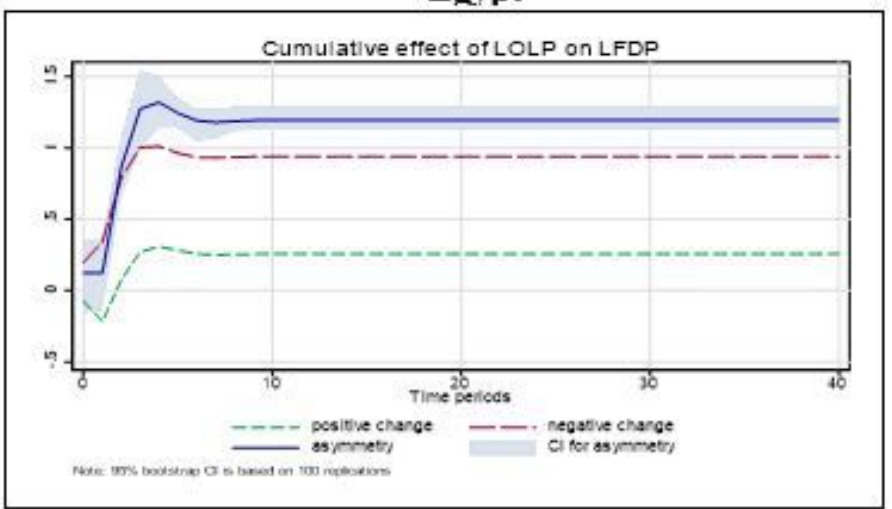

Lebanon

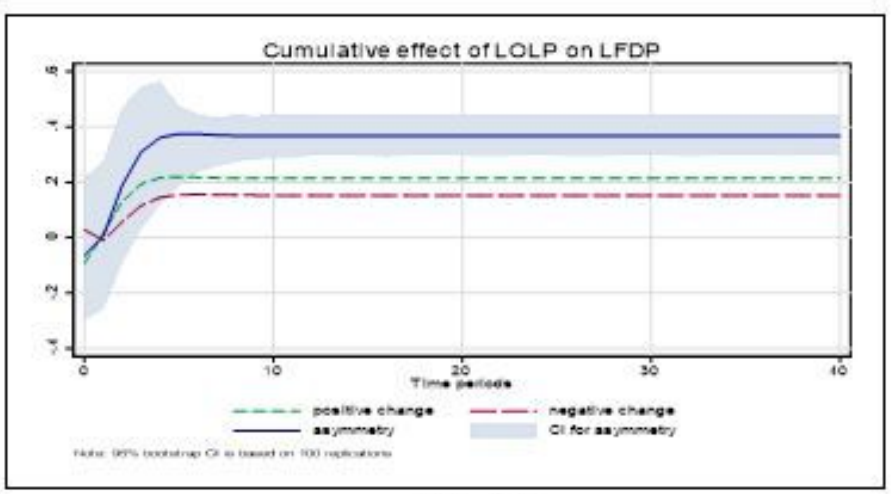

Tunisia

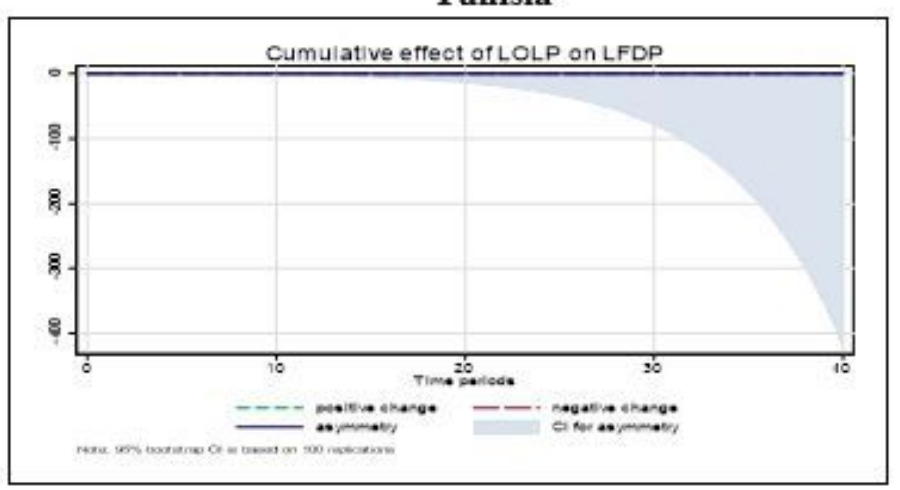

Jordan

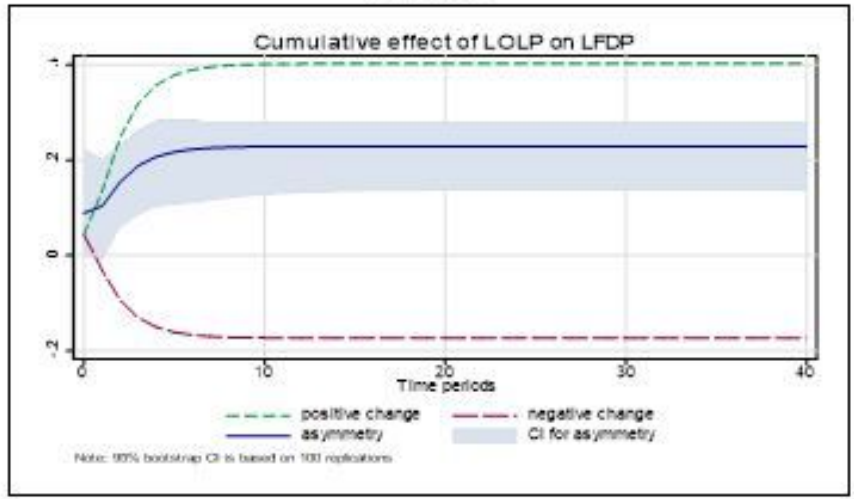

Morocco
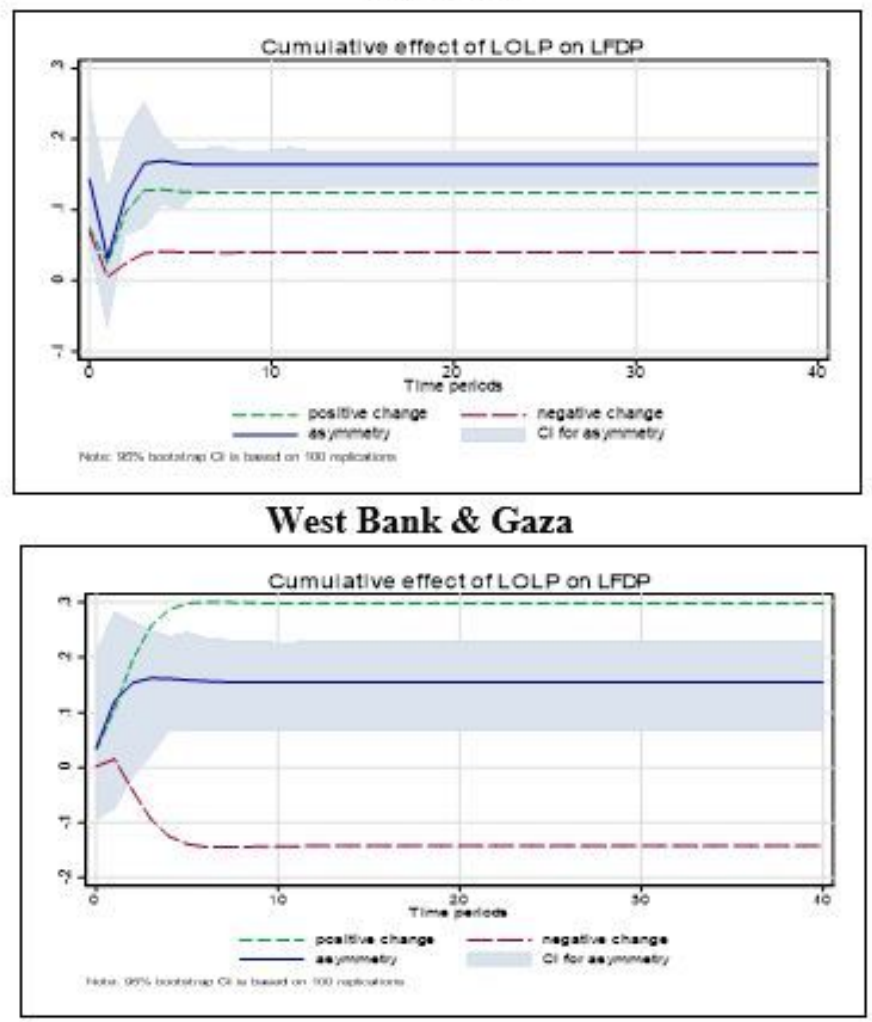

Figure 2

The cumulative effect of oil price on food price in oil-importers group 